NASA/TM-2003-212531

Toward an Improved Hypersonic Engine Seal

Patrick H. Dunlap, Jr. and Bruce M. Steinetz

Glenn Research Center, Cleveland, Ohio

Jeffrey J. DeMange

University of Toledo, Toledo, Ohio

Shawn C. Taylor

Case Western Reserve University, Cleveland, Ohio 
Since its founding, NASA has been dedicated to the advancement of aeronautics and space science. The NASA Scientific and Technical Information (STI) Program Office plays a key part in helping NASA maintain this important role.

The NASA STI Program Office is operated by Langley Research Center, the Lead Center for NASA's scientific and technical information. The NASA STI Program Office provides access to the NASA STI Database, the largest collection of aeronautical and space science STI in the world. The Program Office is also NASA's institutional mechanism for disseminating the results of its research and development activities. These results are published by NASA in the NASA STI Report Series, which includes the following report types:

- $\quad$ TECHNICAL PUBLICATION. Reports of completed research or a major significant phase of research that present the results of NASA programs and include extensive data or theoretical analysis. Includes compilations of significant scientific and technical data and information deemed to be of continuing reference value. NASA's counterpart of peerreviewed formal professional papers but has less stringent limitations on manuscript length and extent of graphic presentations.

- TECHNICAL MEMORANDUM. Scientific and technical findings that are preliminary or of specialized interest, e.g., quick release reports, working papers, and bibliographies that contain minimal annotation. Does not contain extensive analysis.

- CONTRACTOR REPORT. Scientific and technical findings by NASA-sponsored contractors and grantees.
- CONFERENCE PUBLICATION. Collected papers from scientific and technical conferences, symposia, seminars, or other meetings sponsored or cosponsored by NASA.

- SPECIAL PUBLICATION. Scientific, technical, or historical information from NASA programs, projects, and missions, often concerned with subjects having substantial public interest.

- TECHNICAL TRANSLATION. Englishlanguage translations of foreign scientific and technical material pertinent to NASA's mission.

Specialized services that complement the STI Program Office's diverse offerings include creating custom thesauri, building customized databases, organizing and publishing research results ... even providing videos.

For more information about the NASA STI Program Office, see the following:

- Access the NASA STI Program Home Page at http://www.sti.nasa.gov

- E-mail your question via the Internet to help@sti.nasa.gov

- Fax your question to the NASA Access Help Desk at 301-621-0134

- Telephone the NASA Access Help Desk at 301-621-0390

- Write to:

NASA Access Help Desk

NASA Center for AeroSpace Information 7121 Standard Drive

Hanover, MD 21076 
NASA/TM-2003-212531

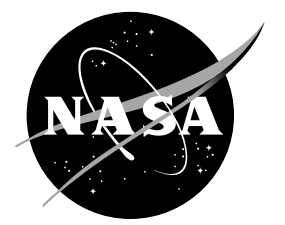

\section{Toward an Improved Hypersonic Engine Seal}

Patrick H. Dunlap, Jr. and Bruce M. Steinetz

Glenn Research Center, Cleveland, Ohio

Jeffrey J. DeMange

University of Toledo, Toledo, Ohio

Shawn C. Taylor

Case Western Reserve University, Cleveland, Ohio

Prepared for the

39th Joint Propulsion Conference and Exhibit

cosponsored by AIAA, ASME, SAE, and ASEE

Huntsville, Alabama, July 20-23, 2003

National Aeronautics and

Space Administration

Glenn Research Center 


\section{Acknowledgments}

The authors gratefully acknowledge Steve Biddle (Albany International-Techniweave) for fabricating the BC1 seal design and Dick Tashiian (QSS Group, Inc.) and

Steve DeBarr (NASA Glenn Research Center) for their assistance in test support.

Trade names or manufacturers' names are used in this report for identification only. This usage does not constitute an official endorsement, either expressed or implied, by the National Aeronautics and Space Administration.

Available from

NASA Center for Aerospace Information 7121 Standard Drive

Hanover, MD 21076
National Technical Information Service 5285 Port Royal Road Springfield, VA 22100

Available electronically at http:/ /gltrs.grc.nasa.gov 


\title{
TOWARD AN IMPROVED HYPERSONIC ENGINE SEAL
}

\author{
Patrick H. Dunlap, Jr.* and Bruce M. Steinetz ${ }^{\dagger}$ \\ National Aeronautics and Space Administration \\ Glenn Research Center \\ Cleveland, Ohio 44135 \\ Jeffrey J. DeMange* \\ University of Toledo \\ Toledo, Ohio 43606 \\ Shawn C. Taylor \\ Case Western Reserve University \\ Cleveland, Ohio 44106
}

High temperature, dynamic seals are required in advanced engines to seal the perimeters of movable engine ramps for efficient, safe operation in high heat flux environments at temperatures from 2000 to $2500{ }^{\circ} \mathrm{F}$. Current seal designs do not meet the demanding requirements for future engines, so NASA's Glenn Research Center (GRC) is developing advanced seals to overcome these shortfalls. Two seal designs and two types of seal preloading devices were evaluated in a series of compression tests at room temperature and $2000^{\circ} \mathrm{F}$ and flow tests at room temperature. Both seals lost resiliency with repeated load cycling at room temperature and $2000^{\circ} \mathrm{F}$, but seals with braided cores were significantly more flexible than those with cores composed of uniaxial ceramic fibers. Flow rates for the seals with cores of uniaxial fibers were lower than those for the seals with braided cores. Canted coil springs and silicon nitride compression springs showed promise conceptually as potential seal preloading devices to help maintain seal resiliency.

\section{INTRODUCTION AND BACKGROUND}

High temperature, dynamic structural seals are required in advanced hypersonic engines to seal the perimeters of movable engine ramps for efficient, safe operation in high heat flux environments at temperatures from 2000 to $2500{ }^{\circ} \mathrm{F}$. Seals must be flexible enough to accommodate distorted walls and provide positive, resilient sealing. They also must be sufficiently durable to meet required engine life goals.

NASA GRC became involved in the development of high temperature structural seals in the late 1980's and early 1990's during the National Aerospace Plane (NASP) program. Researchers at GRC (then called the Lewis Research Center) carried out an in-house program to develop seals for the NASP hypersonic engine and oversaw industry efforts for airframe and propulsion system seal development for this vehicle. ${ }^{1}$ Figure 1 shows one of the seal locations in the NASP engine. Seals were needed along the edges of movable

*Mechanical Engineer, Mechanical Components Branch, Member AIAA.

${ }^{\dagger}$ Senior Research Engineer, Mechanical Components Branch, Member AIAA.

${ }^{\ddagger}$ Senior Research Associate, University of Toledo, Mechanical Components Branch, Member AIAA.

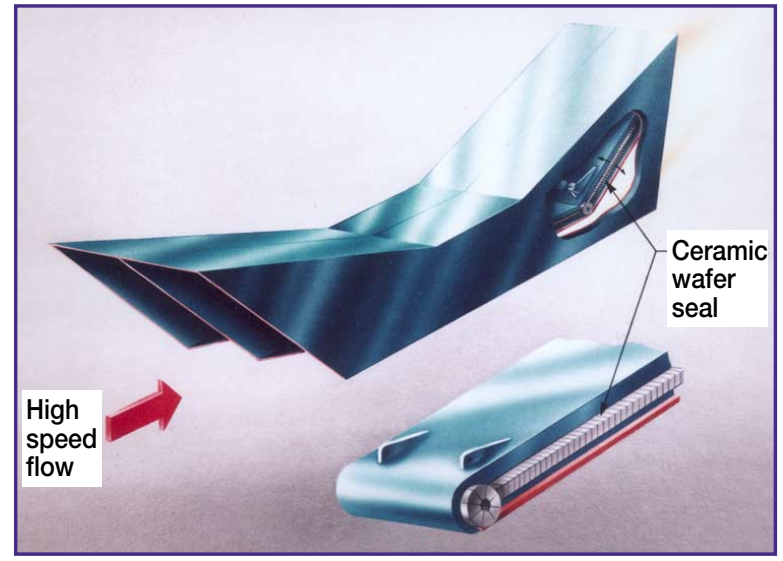

Figure 1.-NASP engine panel edge seals designed to seal the gaps between the movable ramps and adjacent engine sidewalls. 
panels in the engine to seal gaps between the panels and adjacent engine sidewalls. Seal development efforts undertaken during the NASP program became the basis for current seal development activities at GRC to meet the seal challenges of future hypersonic and reentry vehicles.

Seals developed during the NASP program met many requirements but fell short of leakage and durability goals and due to program termination could not be adequately matured. These seals also do not meet future engine reusability requirements because they lose resiliency when they are repeatedly loaded at high temperatures. To overcome these shortfalls, GRC is currently developing advanced seals and seal preloading devices for the hypersonic engines of future space vehicles as part of NASA's Next Generation Launch Technology (NGLT) program.

\section{CHALLENGES AND OBJECTIVES} FOR SEAL DEVELOPMENT

High temperature structural seals have been identified as a critical technology in the development of future space vehicles. Seals in hypersonic propulsion systems are expected to reach very high temperatures and operate in a chemically hostile environment in which oxidation and hydrogen embrittlement can occur. Analyses of panel-edge seals in the inlet of the NASP engine predicted seal temperatures of up to $2100{ }^{\circ} \mathrm{F}$. However, similar seals in the entrance region of the NASP engine combustor were expected to reach temperatures as high as $4900^{\circ} \mathrm{F}$ at Mach 10. Even higher temperatures were possible if the vehicle stayed in scramjet mode for a longer time at higher Mach numbers. Because no existing materials could withstand those temperatures, active cooling of the seals was planned to ensure that they would survive in the combustor and nozzle regions. A cooling system inevitably comes with a weight penalty due to the plumbing lines, tanks, valves, and coolant gas associated with it. Ideally future propulsion system seals would operate at the flowpath temperature without coolant. However, the presence of steam and an oxidizing environment limit uncooled seal temperatures to the upper use temperatures of modern engineering ceramic materials. In regions where gas temperatures exceed material limits, some use of active cooling will be required.

In addition to operating at very high temperatures, seals must also remain resilient after repeated loading to ensure that they stay in contact with their sealing surfaces and restrict the flow of hot gases (Figure 2).

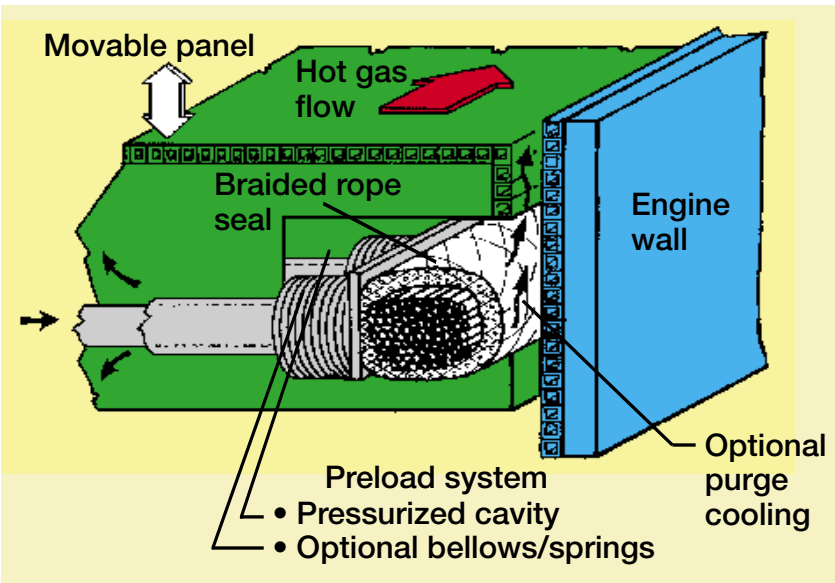

Figure 2.-Schematic of braided rope seal designed to seal the gaps between the edges of movable ramps and adjacent engine sidewalls.

Current state-of-the-art (SOA) braided rope seals for propulsion systems take on a permanent set when they are repeatedly loaded and unloaded. ${ }^{3}$ Even at room temperature they lose as much as 60 percent of their stroke with repeated loading. This loss of spring back compromises the seals' ability to stay in sealing contact with adjacent walls with potentially disastrous effects.

Clearly a large technology gap exists in the current SOA for structural seals. It is GRC's goal to develop robust, reusable seals that can operate at higher temperatures for longer periods of time while still remaining resilient. The objective is to produce a sealing system that would have a permanent set of far less than 60 percent of its stroke at $2000+{ }^{\circ} \mathrm{F}$. These advanced seals will be evaluated and their performance will be demonstrated through testing in simulated environments to ultimately develop seals that fill this technology gap.

\section{SEAL DESIGN REQUIREMENTS}

Hypersonic engine seals have a demanding set of design requirements as shown in Table 1. To meet engine performance, safety, and life goals, they must withstand temperatures up to $2500{ }^{\circ} \mathrm{F}$ with minimal active cooling to limit the amount of complex, heavy hardware that cooling systems would add to the engine. Inlet mass addition caused by purge cooling the seals could affect inlet performance and stability thereby increasing the chance of engine unstart. Because of this, hypersonic engine inlet designers would prefer inlet seals that do not require purge cooling. Engine seals must limit the leakage of hot, pressurized ( 100 psi) gases and unburned propellant into backside cavities to 
Table 1.-Hypersonic engine seal design requirements

\begin{tabular}{|l|c|}
\hline \multicolumn{1}{|c|}{ Design Requirement } & Goal \\
\hline Seal temperature & Up to $2500^{\circ} \mathrm{F}$ \\
\hline Gas temperatures near seal & $\sim 5000^{\circ} \mathrm{F}$ \\
\hline Pressure drop across seal & $100 \mathrm{psi}$ (ref. 1$)$ \\
\hline Leakage & Minimize \\
\hline Heat flux & Up to 2000 Btu/ft ${ }^{2}$-sec \\
\hline Environmental considerations & $\begin{array}{c}\text { Oxidizing and steam environment; } \\
\text { possible hydrogen embrittlement }\end{array}$ \\
\hline Use of cooling: Inlet & Prefer to operate without active cooling \\
\hline Use of cooling: Combustor and nozzle & Operate with minimal cooling \\
\hline Flight time & $\sim 2500$ sec $(\sim 42$ min) \\
\hline Reusability & TBD-nominally 10 to 100 cycles \\
\hline Flexibility & $\begin{array}{c}\text { Accommodate engine side wall } \\
\text { non-uniformities and distortions }\end{array}$ \\
\hline Resiliency & Accommodate seal gap openings and closings \\
\hline Seal gap size & $\begin{array}{c}0.03 \text { in. to } 0.15 \text { in.; } \\
\text { gap variation of } 0.15 \text { in. over } 18 \text { in. span (ref. } 1)\end{array}$ \\
\hline Sliding speed & 1 in./sec (ref. 1) \\
\hline Wear resistance & Withstand scrubbing against rough surfaces \\
\hline
\end{tabular}

prevent explosive mixtures from forming there. The seals must operate in an oxidizing/steam environment and resist hydrogen embrittlement if hydrogen is used as a propellant. Structural and thermal loads on the engine sidewalls can cause distortions that the seals must accommodate. To stay in contact with the walls, the seals must remain resilient and flexible for multiple heating cycles. The seals will also be rubbed over these distorted, rough walls as the engine panels that hold the seals are actuated. The seals must survive the hot scrubbing without incurring increases in leakage due to wear.

\section{SEAL PRELOADING DEVICE REQUIREMENTS}

In addition to designing more resilient seals, GRC is evaluating high temperature seal preloading devices as an additional approach to improve seal resiliency. These devices

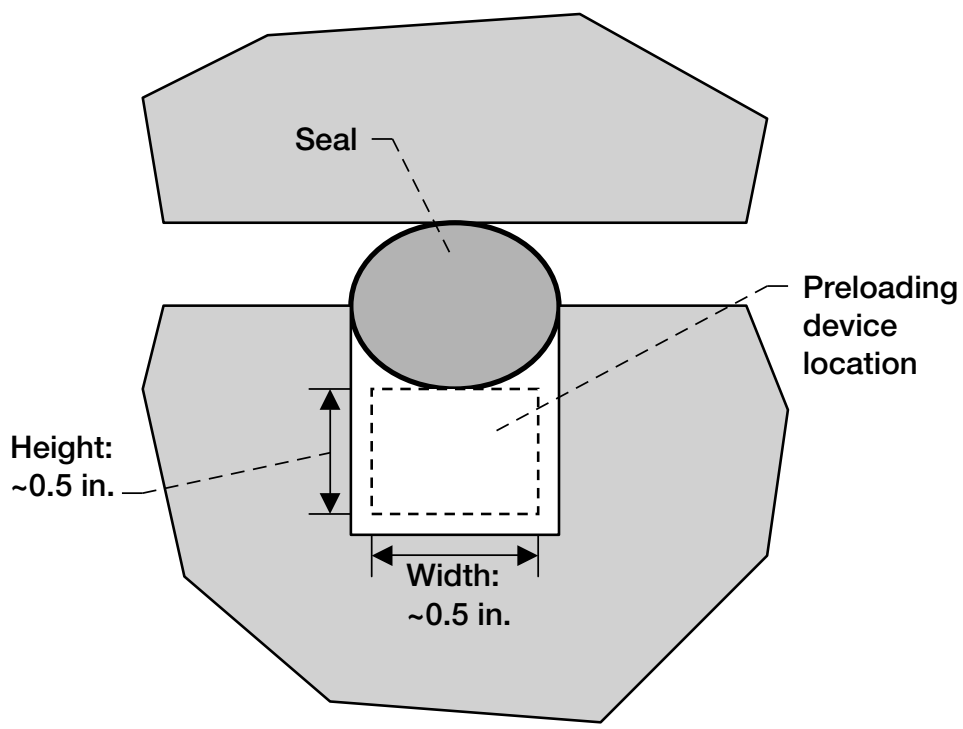

Figure 3.-Cross sectional model of seal showing location and space limitations for preloading device. would be installed behind the seals to ensure

sealing contact with the opposing sealing surfaces (Figure 3). The requirements for these devices are also quite challenging. They must operate at $2000+{ }^{\circ} \mathrm{F}$ in the same environment while providing the required stroke (nominally 0.1 in.) with a permanent set of less than 20 percent of that stroke for multiple loading and heating cycles. Complicating this effort further is the limited amount of space available for the preloader behind the seals. The cross sectional area of the device must fit in a space that is about $0.5 \mathrm{in}$. wide by about $0.5 \mathrm{in}$. high. Ideally the device would be about as long as the seal and able to be installed around corners. The device must be stiff enough to support the seal and keep it pressed against the sealing surface but soft enough that it does not apply excessive loads to that surface. 


\section{TEST APPARATUS AND PROCEDURES}

Seal Specimens

Two seal designs were examined in this study. The first seal was a braided rope seal design originally developed by GRC during the NASP program (Figure 2). ${ }^{1}$ Nominally 0.600-in. in diameter (actual range was 0.576 to $0.622 \mathrm{in}$.), it consisted of a dense uniaxial core of Nextel 312 fibers overbraided with two sheath layers of Nextel 550 fibers (Table 2). This seal design will hereafter be referred to as the AC1 design. Advanced seal designs are being compared to this baseline design.

One approach being pursued to improve the resiliency of the basic braided rope seal design is to modify the structure of the core of the seal. The current core of uniaxial fibers provides little resiliency to the seals. To improve the design of the core and increase seal resiliency, GRC designed a seal with a core composed of smaller braided rope seals that were braided together
(Table 3 and Figure 4). The core of this seal was composed of three layers of 0.062-in.-diameter rope seals in different configurations. The innermost layer of the core was made up of 7 of these seals in a uniaxial arrangement. Eight seals were braided over the inner layer to form the middle layer of the core, and then 16 seals were braided over the middle layer to form the outer layer of the core. Over this engineered core, two sheath layers were then braided to create a nominal overall diameter of about 0.565 in. (actual range was 0.560 to 0.595 in.). This seal design was made entirely of Nextel 440 ceramic fibers and will hereafter be referred to as the $\mathrm{BC} 1$ design.

All seals that were tested in this study were heat cleaned at $1022^{\circ} \mathrm{F}$ for $12 \mathrm{hrs}$ before testing. This was done to remove any sizing that might still be present on the ceramic fibers from the seal fabrication process.

Table 2.-Construction matrix for AC1 braided rope seal design

\begin{tabular}{|c|c|c|c|c|c|c|c|c|c|c|}
\hline $\begin{array}{c}\text { Seal } \\
\text { type }\end{array}$ & Size & \multicolumn{5}{|c|}{ Core } & \multicolumn{5}{c|}{ Sheath } \\
\hline & $\begin{array}{c}\text { Nominal } \\
\text { diameter, } \\
\text { in. }\end{array}$ & Material & Denier & $\begin{array}{c}\text { Number } \\
\text { of yarns }\end{array}$ & $\begin{array}{c}\text { Core } \\
\text { area, } \\
\text { percent }\end{array}$ & Material & Denier & $\begin{array}{c}\text { Filament } \\
\text { diameter, } \\
\text { in. }\end{array}$ & $\begin{array}{c}\text { Number } \\
\text { of } \\
\text { layers }\end{array}$ & $\begin{array}{c}\text { Number } \\
\text { of yarns } \\
\text { per tow }\end{array}$ \\
\hline AC1 & 0.600 & $\begin{array}{c}\text { Nextel } \\
312\end{array}$ & 600 & 4000 & 83 & $\begin{array}{c}\text { Nextel } \\
550\end{array}$ & 2000 & 0.00048 & 2 & 2 \\
\hline
\end{tabular}

${ }^{\mathrm{a}}$ Actual range was 0.576 to 0.622 in.

Table 3.-Construction matrix for BC1 braided rope seal design (see Figure 4 for additional details)

\begin{tabular}{|c|c|c|}
\hline Seal component & Design characteristic & Value \\
\hline \multirow[t]{2}{*}{ Overall BC1 seal } & Nominal diameter, ${ }^{a}$ in. & 0.565 \\
\hline & Material & Nextel 440 \\
\hline Sheath & Number of layers & 2 \\
\hline \multirow[t]{2}{*}{ Core outer layer } & Number of sub-elements & 16 \\
\hline & Construction & Braided \\
\hline \multirow[t]{2}{*}{ Core middle layer } & Number of sub-elements & 8 \\
\hline & Construction & Braided \\
\hline \multirow[t]{2}{*}{ Core inner layer } & Number of sub-elements & 7 \\
\hline & Construction & Uniaxial \\
\hline \multirow[t]{7}{*}{ Sub-element } & Nominal diameter, in. & 0.062 \\
\hline & Core: yarn denier & 2000 \\
\hline & Core: number of yarns & 1 \\
\hline & Sheath: yarn denier & 2000 \\
\hline & Sheath: number of layers & 1 \\
\hline & Sheath: number of carriers & 4 \\
\hline & Sheath: number of yarns per tow & 2 \\
\hline
\end{tabular}

${ }^{a}$ Actual range was 0.560 to 0.595 in. 


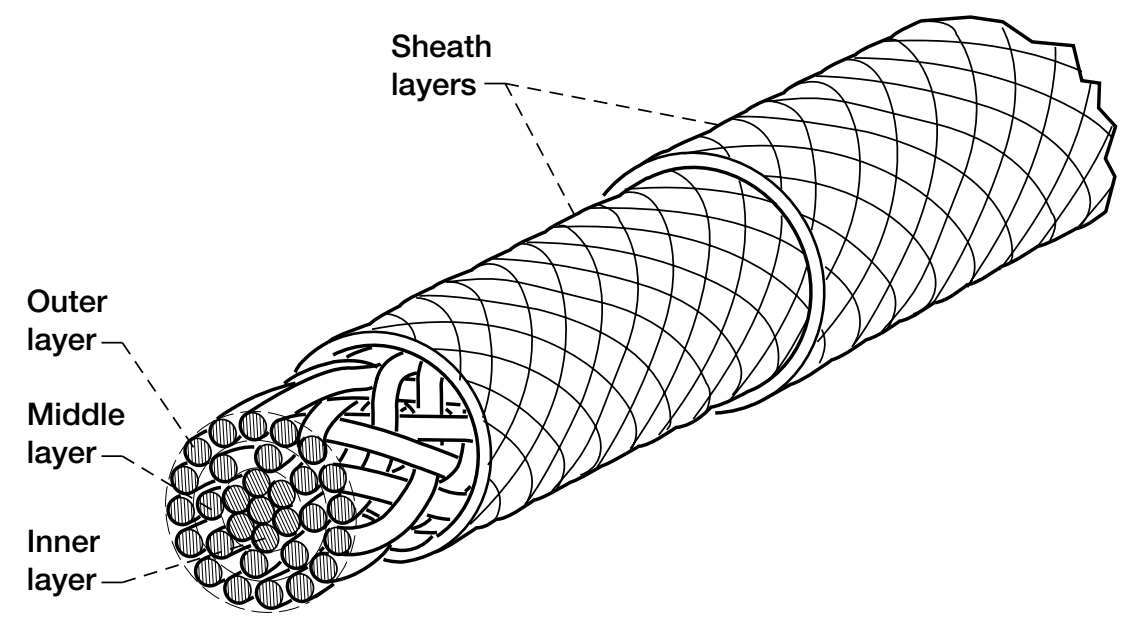

Figure 4.-Schematic of BC1 seal design showing sheath layers and inner, middle, and outer layers of core.

\section{$\underline{\text { Seal Preloading Device Specimens }}$}

Two types of seal preloading devices were evaluated in this study. The first was a canted coil spring produced by Bal Seal Engineering Company, Inc. (Figure 5). These springs have several unique features that could make them very good seal preloading devices. Unlike typical compression springs that generate increasing amounts of force as they are compressed, the force produced by canted coil springs remains nearly constant over a large deflection range. This is an appealing feature for a seal preloading device because it could provide a large amount of stroke and resiliency to a seal without applying excessive loads to the seal or the opposing sealing surfaces. Another advantageous feature of canted coil springs is that they are produced in long, linear lengths that would allow them to be installed in a groove directly behind a seal and potentially around corners. Additionally, the part count would be far lower for a canted coil spring than for a typical compression spring because hundreds of compression springs would have to be lined up behind a long seal to accomplish what only a few canted coil springs could do.

The canted coil springs evaluated in this study were Bal Seal part number 109MB-(84)L-2 and were made of 302 stainless steel (Table 4). Stainless steel springs were used to investigate the initial feasibility of this seal preloader concept. The work performed herein forms the basis for future studies where canted coil springs made of high temperature materials would be investigated. A series of room temperature compression and flow tests were performed using this stainless steel spring design to evaluate it as a potential preloading device.

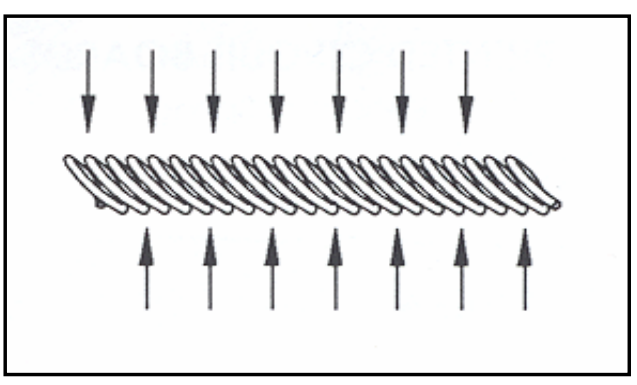

Figure 5.-Schematic of canted coil spring under transverse loading.

Another concept that was evaluated as a potential seal preloading device was a silicon nitride compression spring produced by NHK Spring Co., Ltd. Two different designs were tested: a standard spring (Specification No. NCS2-025S) and a modified design (Specification No. NCSS-02618DOB). Design specifications from the manufacturer for these springs are given in Table 4. Because they are made of silicon nitride, these springs have the potential to be used as high temperature seal preloading devices. Product literature claims that the strength of these springs will not decrease significantly at service temperatures up to $1832{ }^{\circ} \mathrm{F}$ and that the strength maintains a level of $29 \mathrm{ksi}$ with a failure probability of 0.1 percent at up to $2192{ }^{\circ} \mathrm{F}$. ${ }^{4}$ A series of compression tests were performed on the springs at both room temperature and $2000^{\circ} \mathrm{F}$ to evaluate these claims. 
Table 4.-Design specifications for seal preloading devices

\begin{tabular}{|l|c|c|c|c|c|c|c|}
\hline Spring design & Material & Part number & $\begin{array}{c}\text { Wire } \\
\text { diameter, } \\
\text { in. }\end{array}$ & $\begin{array}{c}\text { Coil } \\
\text { height, } \\
\text { in. }\end{array}$ & $\begin{array}{c}\text { Coil } \\
\text { width, } \\
\text { in. }\end{array}$ & $\begin{array}{c}\text { Max. } \\
\text { deflection, a } \\
\text { in. }\end{array}$ & $\begin{array}{c}\text { Max. } \\
\text { load, a } \\
\text { lbf }\end{array}$ \\
\hline $\begin{array}{l}\text { Bal Seal canted } \\
\text { coil spring }\end{array}$ & $\begin{array}{c}302 \\
\text { stainless } \\
\text { steel }\end{array}$ & $\begin{array}{c}109 \mathrm{MB}- \\
(84) \mathrm{L}-2\end{array}$ & 0.041 & 0.450 & 0.508 & & \\
\hline $\begin{array}{l}\text { NHK standard } \\
\text { compression } \\
\text { spring }\end{array}$ & $\begin{array}{c}\text { Silicon } \\
\text { nitride }\end{array}$ & NCS2-025S & 0.065 & 0.815 & 0.520 & 0.098 & 5.5 \\
\hline $\begin{array}{l}\text { NHK modified } \\
\text { compression } \\
\text { spring }\end{array}$ & $\begin{array}{l}\text { Silicon } \\
\text { nitride }\end{array}$ & $\begin{array}{c}\text { NCSS- } \\
\text { 02618DOB }\end{array}$ & 0.065 & 0.694 & 0.435 & 0.043 & 5.5 \\
\hline
\end{tabular}

${ }^{a}$ Per manufacturer's specifications

\section{Compression Tests}

Test Apparatus - A series of room temperature and $2000^{\circ} \mathrm{F}$ compression tests were performed on the seals and preloading devices using a new SOA test rig that was recently installed at GRC. This test rig is capable of performing either high temperature seal compression tests or scrub tests at temperatures of up to $3000{ }^{\circ} \mathrm{F}$ by using different combinations of test fixtures made of monolithic silicon carbide (Hexoloy $\alpha-\mathrm{SiC}$ ). The main components of this test rig are a servohydraulic load frame, an air furnace, and a non-contact laser extensometer. The load frame has a top-mounted actuator capable of generating a load of $3300 \mathrm{lb}$ over a 6 in. stroke (Figure 6). Dual servovalves control movement of the actuator at rates from 0.001 to $8 \mathrm{in} . / \mathrm{sec}$. This allows the actuator to move very slowly for the compression tests or quickly for the scrub tests. Computer control of the hydraulic system permits a mission-simulated duty cycle to be used during testing. Cyclic loading compression tests can be performed in which test specimens are loaded and unloaded for many cycles. Stress relaxation tests can also be performed in which a specimen is put under a specified amount of compression and then held in that state for a period of time. Tests can be performed in either load control or displacement control. In displacement control, feedback from the LVDT inside the actuator controls actuator movement. When the LVDT is used in its lowest calibration range of \pm 0.5 in., it has an accuracy of \pm 0.0017 in.

The box furnace is installed between the columns of the load frame so that the loading rod of the actuator is able to transmit loads through a penetration in the top of the furnace. A water-cooled coupling connected to the bottom of this loading rod protects the actuator from heat that is conducted out of the furnace. The furnace has a working volume that is $9 \mathrm{in}$. wide by $14 \mathrm{in}$. deep by $18 \mathrm{in}$. high. Front and back doors provide access to the inside of the furnace from opposite sides, and a removable split plug in the top of the furnace provides access from above. Kanthal Super 33 molybdenum disilicide $\left(\mathrm{MoSi}_{2}\right)$ heating elements heat the furnace to temperatures up to $3000^{\circ} \mathrm{F}$.

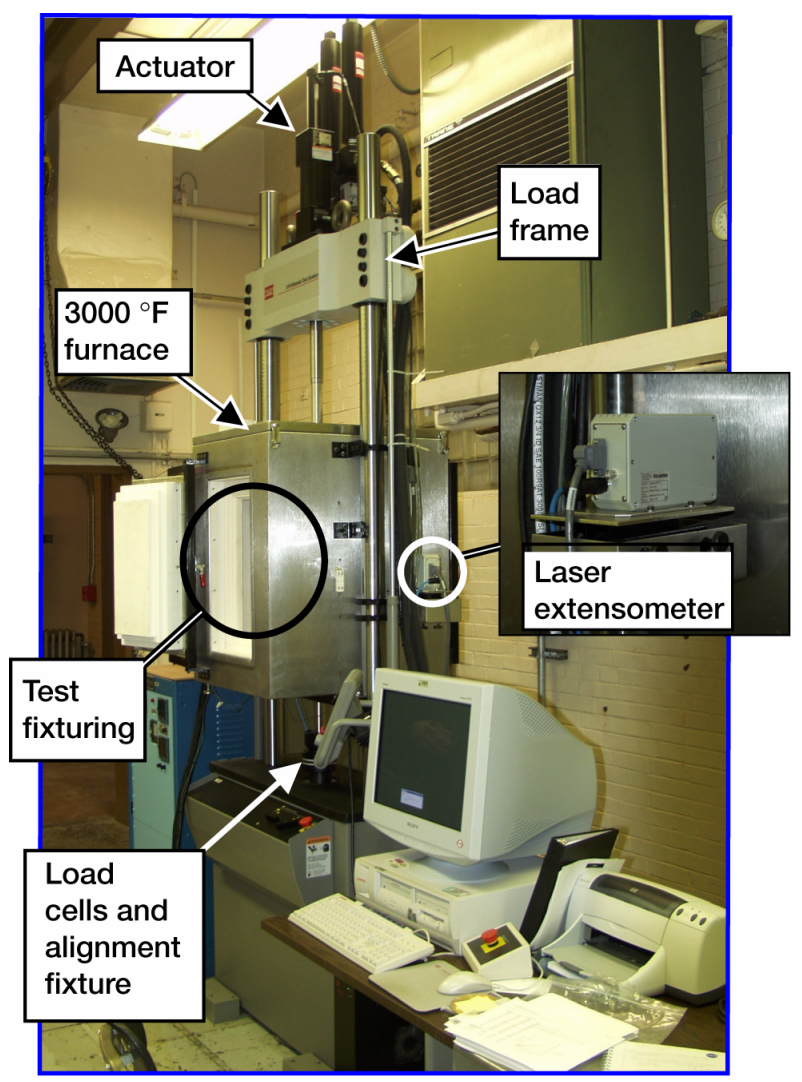

Figure 6.-Photograph of hot compression and scrub test rig showing main components: load frame, high temperature furnace, and laser extensometer. 
The stationary base for each set of test fixtures rests on a column that passes through an opening in the bottom of the furnace. The bottom of this column is connected to a water-cooled coupling that sits on top of and protects a load cell. Two different load cell ranges are available, 500 or $3300 \mathrm{lb}$, depending on the seal that is being tested and the loads that are expected during a test. The $500 \mathrm{lb}$ load cell has an accuracy of $\pm 0.15 \mathrm{lb}$ ( \pm 0.03 percent of full scale), and the accuracy of the $3300 \mathrm{lb}$ load cell is $\pm 2.64 \mathrm{lb}$ ( \pm 0.08 percent of full scale). The load cells are used to measure compressive loads applied to the seals during a compression test or frictional loads on the seals during scrub testing. Below the load cell is an alignment fixture that permits precise alignment of the load train.

Compression Test Fixture-Compression tests were performed inside the furnace using the test set up shown in Figure 7. These tests were performed to determine seal resiliency and stiffness and to generate seal load versus displacement (i.e., linear compression) data at room temperature and $2000{ }^{\circ} \mathrm{F}$. Seals or preloading devices were installed into a seal holder that rested on the stationary base described above. Test specimens were nominally 4 in. long. A movable platen was attached to a loading rod that passed through the top of the furnace and connected to the water-cooled coupling above the furnace. This platen was actuated up and down to load and unload test specimens. The laser extensometer was used to measure the amount of seal compression during testing (Figure 6). A sheet of laser light produced by the transmitter passed through slots in the furnace walls and was then detected by a receiver on the opposite side of the furnace. Pins attached to the platen and the seal holder blocked portions of the laser sheet and created a pattern that the receiver read. The amount of space between the two pins was determined and the amount of compression on the seal was calculated. This system has a measurement range of up to 2 in. and an accuracy of \pm 0.00025 in.

Test Procedure-The seals and canted coil springs were loaded and unloaded for a total of 20 cycles for each test. The silicon nitride compression springs were tested for 10 cycles. Each load cycle consisted of loading a test specimen at a rate of $0.001 \mathrm{in} / \mathrm{sec}$ to the specified amount of compression, holding at that compression level for $1 \mathrm{~min}$, and then unloading at $0.001 \mathrm{in} / \mathrm{sec}$ to the starting point. There was no hold time after the specimen was unloaded between load cycles. At the start of each test, the movable platen was lowered until it was in contact with the test specimen. "Contact" was defined when there was a load of $1 \mathrm{lb}$ on the test specimen (or $0.25 \mathrm{lb} / \mathrm{in}$. for a 4 -in. specimen). For the room temperature tests, a pressure-sensitive film was placed in between the seal specimens and the movable platen for the first load cycle to determine the contact width and length of the specimen as it was compressively loaded. The film was removed after the first load cycle, and the seal footprint length and width were then used to calculate seal preload in psi. The film could not be used for the tests performed at $2000^{\circ} \mathrm{F}$.

Test Matrix-Room temperature and $2000{ }^{\circ} \mathrm{F}$ compression tests were performed on both seal designs at a compression level of nominally 20 percent. Tests were also performed on the canted coil spring at room temperature. To evaluate the resiliency of the seals in combination with a canted coil spring, tests were performed in which both seal designs were individually tested on top of a spring. These tests were also performed at room temperature. The final series of compression tests were performed on the silicon nitride compression springs at both room temperature and $2000{ }^{\circ} \mathrm{F}$. Primary and repeat tests were performed for each test case, and a new specimen was used for each test. The exact amount of compression applied in each test is summarized in the Results and Discussion section.

\section{Flow Tests}

Room temperature flow tests were performed in a linear flow fixture shown schematically in Figure 8. The flow fixture was designed so that seals of different diameters could be tested in removable cartridges that are inserted into the main body of the test fixture. Seals can be tested in this fixture with different seal gaps and under different amounts of linear compression.

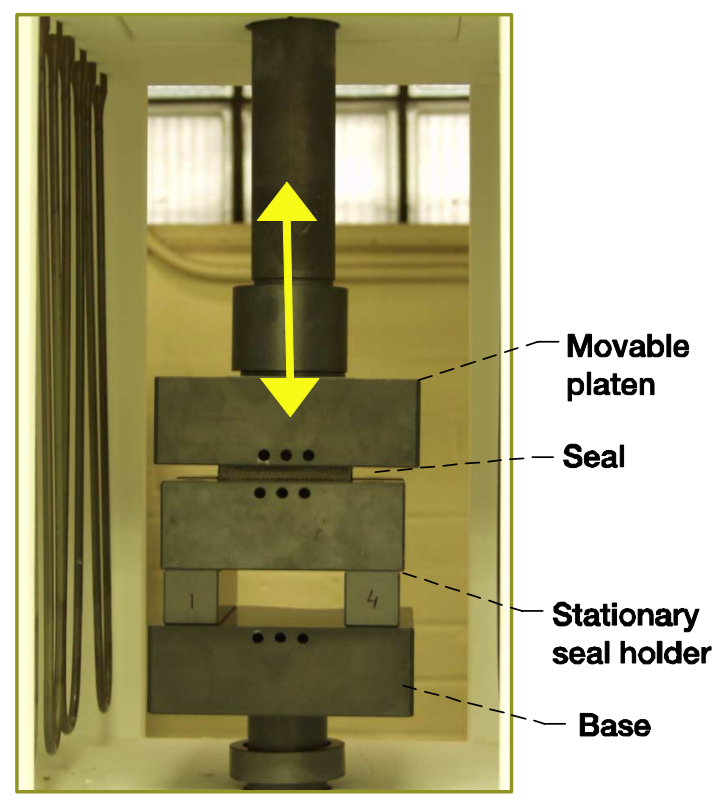

Figure 7.-Photograph of hot compression test fixture setup. 

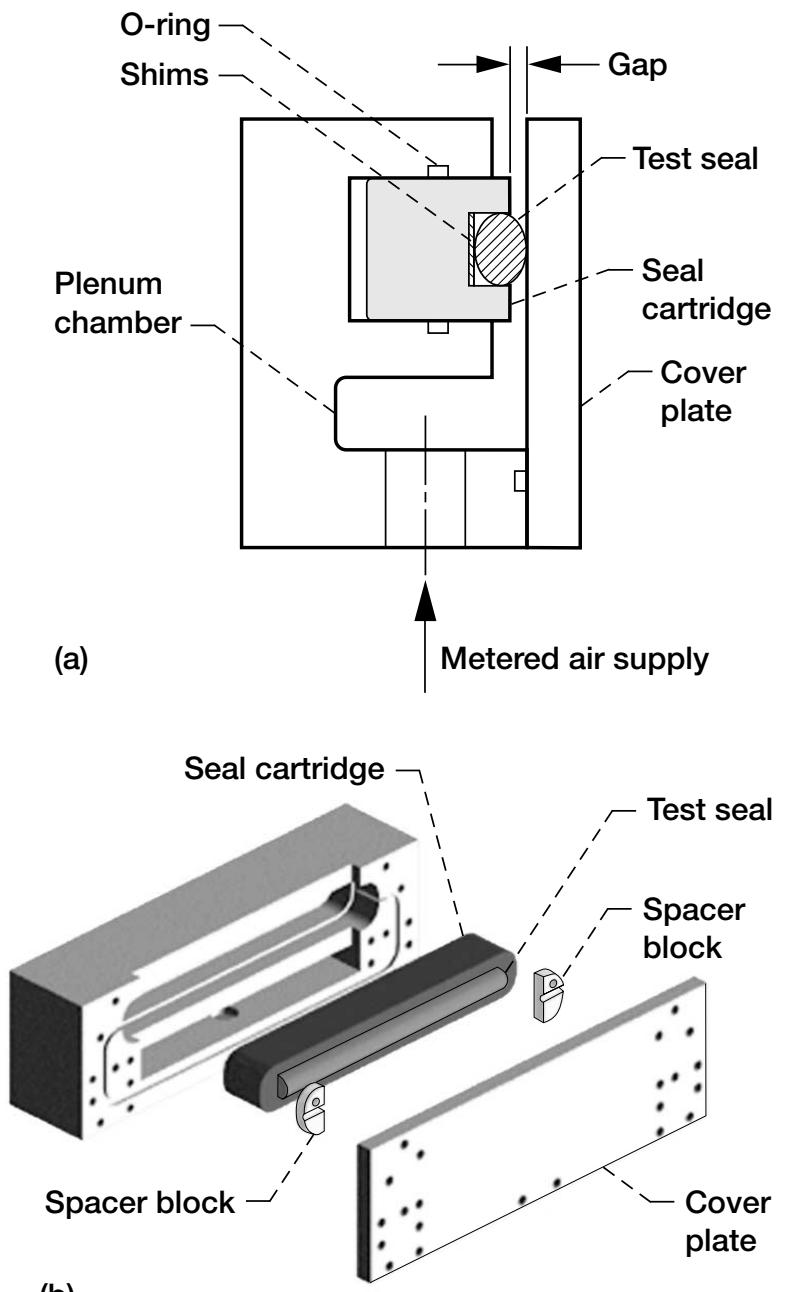

(b)

(c)

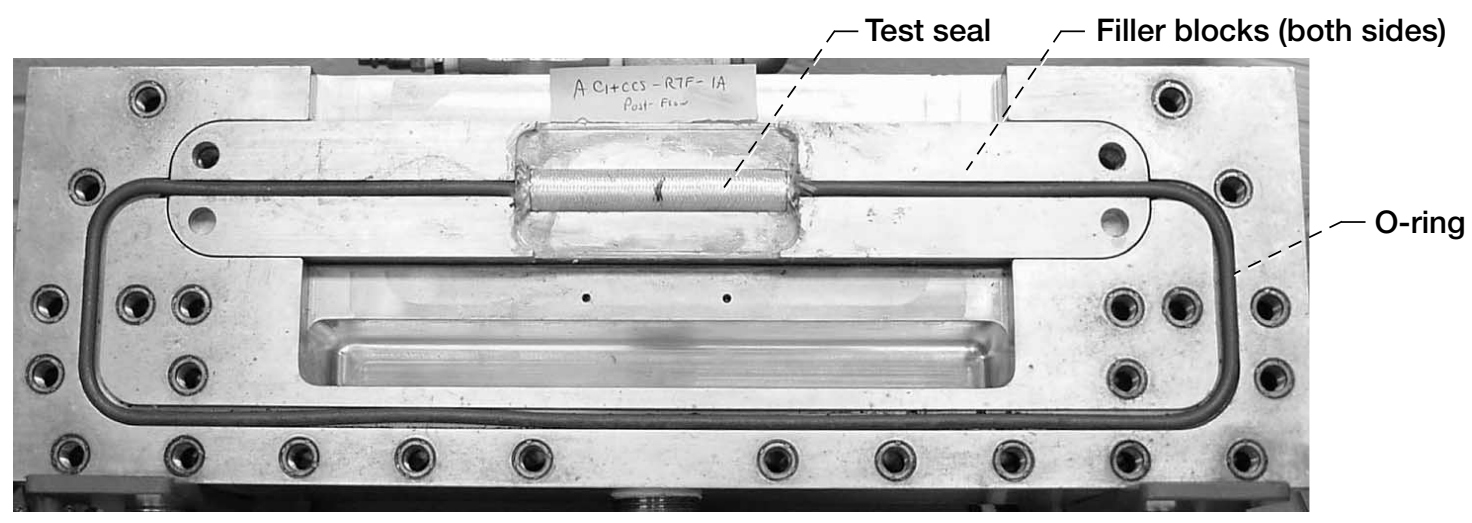

Figure 8.-Schematic of flow fixture. (a) Cross section. (b) Isometric. (c) Front view of 4-in. seal specimen installed in flow fixture showing grooved filler blocks that join O-ring to both ends of seal. 
Flow Path/Instrumentation-During flow testing pressurized air entered through an opening in the base of the fixture and passed through a plenum chamber before reaching the test seal. Air flowed through the gap between the cartridge and the cover plate, passed through the seal and its interface with the cover plate, and then flowed out of the top of the fixture (Figure 8a). Flow meters upstream of the flow fixture measured the amount of flow that passed through the test seal. The maximum capacity flow meter that was used had a range of 0 to 106 standard cubic feet per minute (SCFM) with an accuracy of 1 percent of full scale. A pressure transducer (0 to 100 psid, accuracy 0.074 percent of full scale) upstream of the test seal measured the differential pressure across the seal with respect to ambient conditions, and a thermocouple measured the upstream temperature.

Test Fixture-Test seals were mounted in the groove of a seal holder that was inserted into the test cartridge (Figures $8 \mathrm{~b}$ and $8 \mathrm{c}$ ). The groove was $0.62 \mathrm{in}$. wide and $4 \mathrm{in}$. long. The amount of preload, or linear compression, applied to the seals was varied by placing steel shims in the groove behind the seal. The test fixture was originally set up to test 12-in.-long seals. To test the shorter 4 in. seals, aluminum filler blocks with O-ring grooves in them were installed on either side of the seal assembly to seal the outboard seal ends (Figure 8c).

After a seal specimen was installed in the cartridge, the cartridge was inserted into the test fixture. An Oring sealed the perimeter of the cartridge chamber to prevent flow from passing behind the cartridge during testing. Pairs of spacer blocks secured to the cartridge at the ends of the test specimen controlled the gap width between the cartridge and the cover plate that the seals sealed against (Figures $8 \mathrm{~b}$ and $8 \mathrm{c}$ ). Blocks of different thicknesses could be used to vary the gap width. A small amount of RTV was placed between the spacer blocks, filler blocks, and the cartridge to prevent flow from passing through these gaps. Another O-ring was placed in a groove on the surface of the test fixture and into a groove in the spacer blocks and filler blocks to seal the plenum chamber upstream of the test seal. The ends of this O-ring were pressed up against the ends of the test seal to prevent flow from passing around the ends of the seal. Preload was applied to the test seal through an interference fit between the seal and the cover plate.
Test Matrix - Room temperature flow tests were performed on both seal designs at a compression level of 20 percent of the specimen's overall diameter. These tests were performed on as-received seals and on seals that had been compression tested at $2000^{\circ} \mathrm{F}$. Flow tests were also performed on both seal designs with a canted coil spring installed behind them to determine how this affected the flow blocking ability of each design. These tests were conducted with deeper grooves to account for the height of the springs. Primary and repeat tests were performed for each test case. A new seal specimen was used for each flow test except for the tests that were performed on seals that had been compression tested at $2000^{\circ} \mathrm{F}$. All flow tests were performed with a 0.125 -in. seal gap.

\section{RESULTS AND DISCUSSION}

Compression Test Results: AC1 Seal Design Versus BC1 Seal Design at Room Temperature

Table 5 summarizes the results of all the compression tests performed for this study. The results presented in this table are averages for two tests for every case except the tests performed on the $\mathrm{BC} 1$ seal design at room temperature. The results of three tests were averaged for this test case. The AC1 seal design was subjected to a linear compression of between 0.116 and 0.120 in. for these tests while the $\mathrm{BC} 1$ design was compressed to 0.110 to 0.112 in. At room temperature, both seal designs took on a permanent set with load cycling. With each successive load cycle the amount of seal residual interference decreased. Residual interference was defined as:

$$
\begin{aligned}
\text { Residual interference }= & \text { Total linear compression } \\
& - \text { Permanent set }
\end{aligned}
$$

Residual interference was also defined as the distance the seal would spring back while maintaining a load of at least $0.25 \mathrm{lb}$ per inch of seal against the opposing sealing surface. At the start of the second load cycle, the AC1 design had an average residual interference of 0.068 in. or 58 percent of the total linear compression applied to the seal (Figure 9). By the start of the 20th load cycle, that residual interference dropped to 0.030 in. (26 percent). In comparison, the BC1 seal design with the braided core had a residual interference of 0.053 in. (48 percent) after the first load cycle and 0.029 in. (27 percent) by the start of the 20th load cycle. After 20 load cycles both seal designs had a comparable amount of residual interference. These tests show that the braided core of the $\mathrm{BC} 1$ seal design did not provide more resiliency at room temperature than the uniaxial core of the $\mathrm{AC} 1$ design. 
Table 5.- Seal peak loads and residual interference as a function of temperature and presence of canted coil spring

\begin{tabular}{|c|c|c|c|c|c|c|c|c|c|c|c|c|c|c|c|}
\hline \multirow[b]{2}{*}{ Cycle } & \multicolumn{5}{|c|}{$\begin{array}{l}\text { Peak load at dwell, } \\
\text { lbf/in }\end{array}$} & \multicolumn{5}{|c|}{$\begin{array}{l}\text { Residual interference at } \\
\text { start of load cycle, } \\
\text { in. }\end{array}$} & \multicolumn{5}{|c|}{$\begin{array}{l}\text { Residual interference at } \\
\text { start of load cycle, } \\
\text { percent of original }\end{array}$} \\
\hline & 1 & 2 & 3 & 10 & 20 & 1 & 2 & 3 & 10 & 20 & 1 & 2 & 3 & 10 & 20 \\
\hline $\begin{array}{l}\mathrm{BC} 1 \text { at room } \\
\text { temperature }\end{array}$ & 24.0 & 20.8 & 19.1 & 14.9 & 14.1 & 0.111 & 0.053 & 0.046 & 0.034 & 0.029 & 100 & 48 & 41 & 31 & 27 \\
\hline $\mathrm{BC} 1$ at $2000^{\circ} \mathrm{F}$ & 23.2 & 15.5 & 12.9 & 7.9 & 5.1 & 0.112 & 0.031 & 0.024 & 0.010 & 0.005 & 100 & 28 & 21 & 9 & 5 \\
\hline $\begin{array}{l}\mathrm{AC} 1+\text { canted coil spring } \\
\text { at room temperature }\end{array}$ & 5.0 & 4.9 & 4.8 & 4.6 & 4.7 & 0.120 & 0.099 & 0.092 & 0.078 & 0.071 & 100 & 83 & 77 & 65 & 60 \\
\hline
\end{tabular}

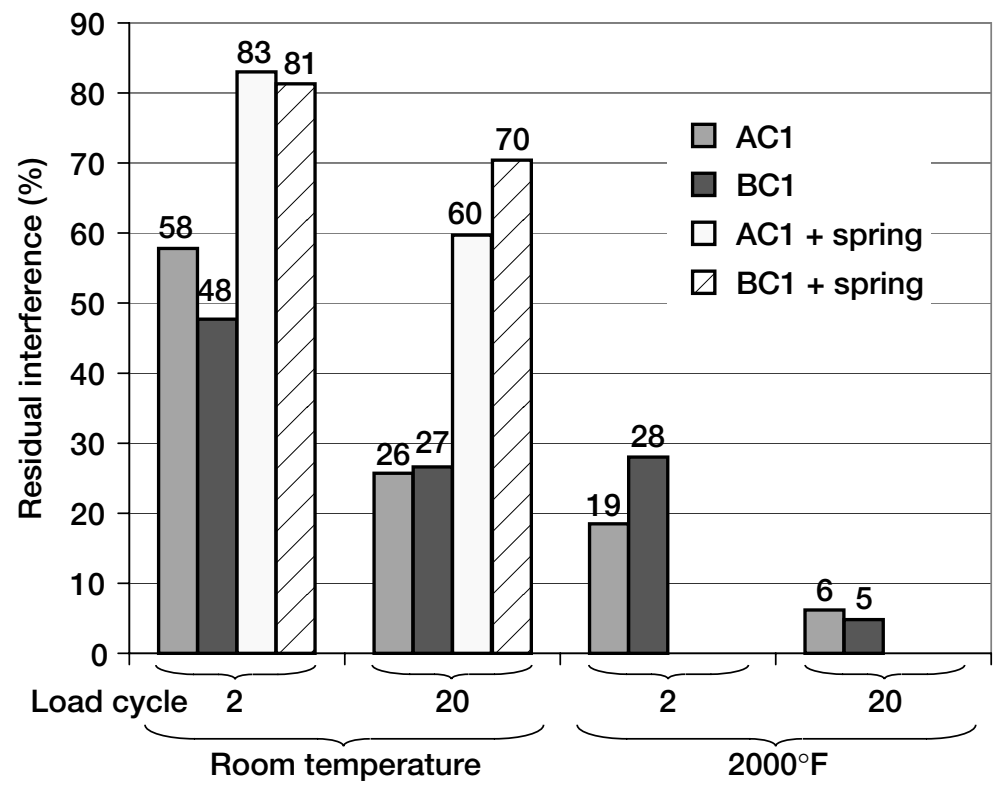

Figure 9.-The effect of temperature, load cycling, and presence of canted coil spring on seal residual interference for nominal 20 percent seal compression. 

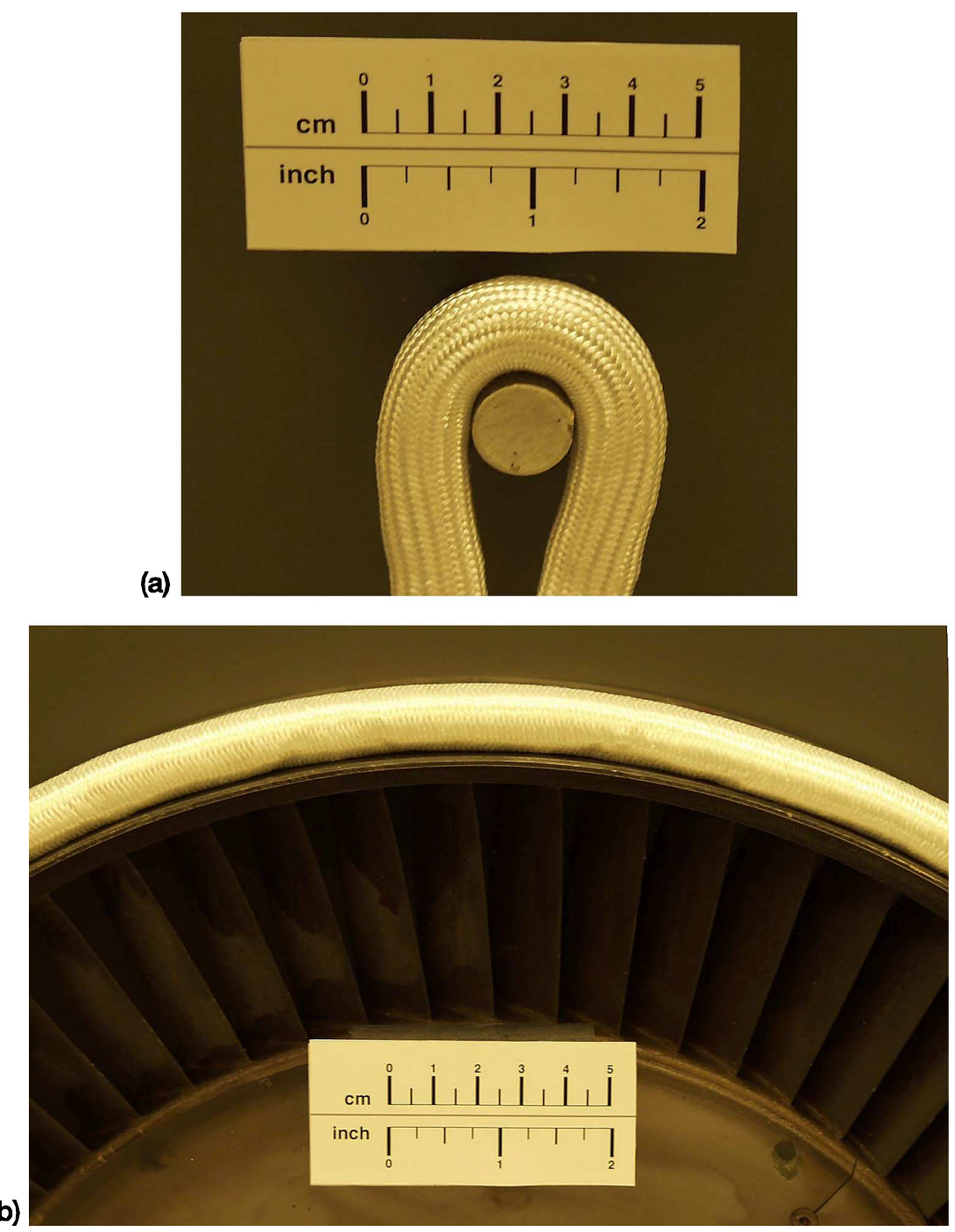

Figure 10.-Photographs of (a) 0.565 -in.-diameter $\mathrm{BC} 1$ seal wrapped around a 0.5 -in.-diameter rod, and (b) 0.600-in.-diameter AC1 seal bent around a 16.4-in.-diameter casing.

Although the $\mathrm{BC} 1$ seal design was about as resilient as the $\mathrm{AC} 1$ design at room temperature, the $\mathrm{BC} 1$ design was much more flexible than the $\mathrm{AC} 1$ design. Figure 10a shows the 0.565-in.-diameter $\mathrm{BC} 1$ seal wrapped around a 0.5-in.-diameter rod, while Figure $10 \mathrm{~b}$ shows the 0.600 -in.-diameter $\mathrm{AC} 1$ seal bent around a 16.4-in.-diameter casing. The AC1 design was so stiff that it could not be wrapped around anything with a smaller diameter. Dividing the $\mathrm{BCl}$ seal diameter by the diameter of the rod it was wrapped around yields a ratio of 1.13 . Doing the same for the $\mathrm{AC} 1$ seal yields a ratio of 0.036 . This means that the $\mathrm{BC} 1$ seal can be seen as 30 times more flexible than the AC1 design. As shown in Table 2, 83 percent of the cross sectional area of the $\mathrm{AC} 1$ design was composed of densely-packed, uniaxial fibers that made the seal very stiff and unbendable. In contrast, the core of the $\mathrm{BC} 1$ seal design was composed of smaller braided rope seals that were braided together to create a much more flexible seal that could easily bend around corners. This is an advantage for future seal applications.

Figure 11 shows a typical plot of load versus linear compression for the $\mathrm{BC} 1$ seal design. This seal showed a large amount of hysteresis in which its unloading curves did not follow its loading curves. Although this plot is for a test performed at $2000^{\circ} \mathrm{F}$, similar behavior was seen at room temperature and for the tests performed on the AC1 seal design. This figure shows data for one of the two tests performed on the $\mathrm{BC} 1$ design at $2000^{\circ} \mathrm{F}$, while the data in Table 5 under these conditions represents an average for two tests.

For its first load cycle, the $\mathrm{AC} 1$ seal reached an average peak load of $56.1 \mathrm{lbf} /$ in. (Table 5 and Figure 12). With a contact width of $0.362 \mathrm{in}$. recorded for the first load cycle, this corresponded to a seal preload of 155 psi. In contrast, the load on the $\mathrm{BC} 1$ seal design for the first load cycle only reached an average of $24.0 \mathrm{lbf} / \mathrm{in}$., 44 percent of that of the AC1 design. It had a contact width for the first load cycle of $0.307 \mathrm{in}$. and a corresponding preload of 81 psi. Although the $\mathrm{AC} 1$ design was stiffer than the $\mathrm{BC} 1$ design for the initial load cycles, the average peak load for the $\mathrm{AC} 1$ design dropped significantly by the 20th load cycle down to $15.3 \mathrm{lbf} / \mathrm{in}$. This load is only 27 percent of the load recorded for the first load cycle. The peak load for the $\mathrm{BC} 1$ design by the 20th load cycle was $14.1 \mathrm{lbf} / \mathrm{in}$., or 57 percent of the load for the first load cycle. This means that the $\mathrm{BC} 1$ design was better able to sustain loads with repeated load cycling at room temperature that the $\mathrm{ACl}$ design was. It is believed that this was due to compaction of the $\mathrm{AC} 1$ seal design into the test fixture groove with load cycling. 


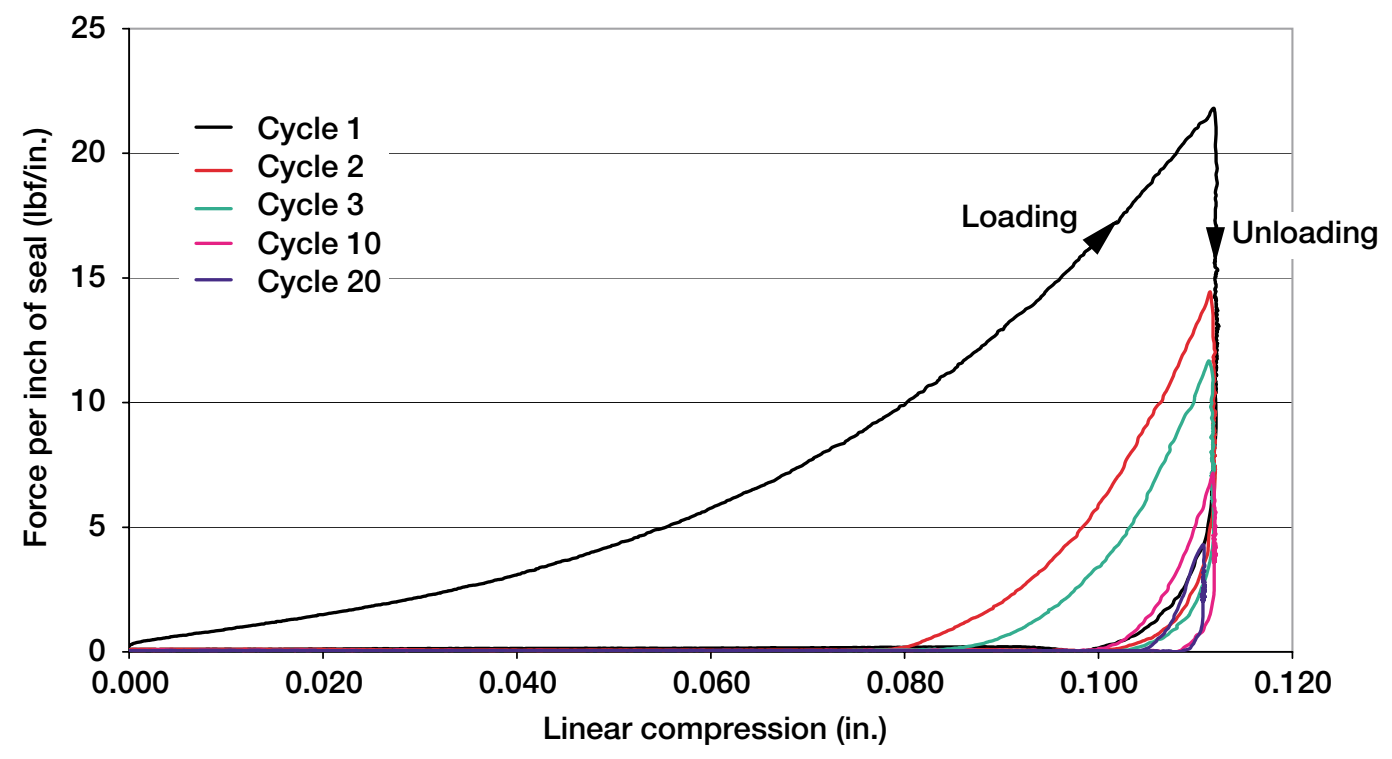

Figure 11.-Load vs. linear compression data for BC1 seal design at $2000{ }^{\circ} \mathrm{F}$ and nominal 20 percent compression (load cycles other than 1, 2, 3, 10, and 20 removed for clarity).

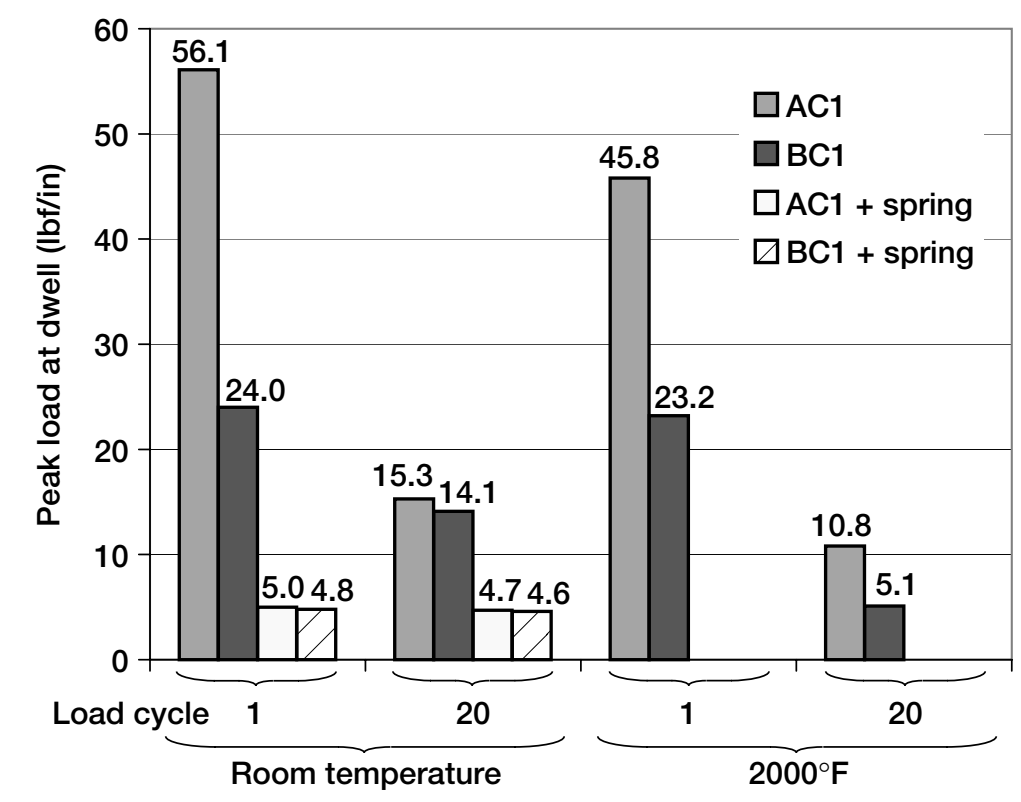

Figure 12.-The effect of temperature, load cycling, and presence of canted coil spring on peak loads for nominal 20 percent seal compression. 


\section{Compression Test Results: AC1 Seal Design Versus}

\section{BC1 Seal Design at $2000^{\circ} \mathrm{F}$}

Both seal designs became less resilient and softer at $2000{ }^{\circ} \mathrm{F}$. Figure 13 shows photographs of both seal designs before and after compression testing at $2000^{\circ} \mathrm{F}$. Both took on a square cross section as they were compressed into the test fixture groove and became quite flat on top where they compressed by the loading platen. Table 5 and Figure 9 show that the residual interference of both seal designs was lower at $2000^{\circ} \mathrm{F}$ than it was at room temperature. At the start of the 20th load cycle at $2000^{\circ} \mathrm{F}$, the $\mathrm{AC} 1$ design had a residual interference of only $0.007 \mathrm{in}$. (or 6 percent of the total linear compression) as compared to 0.030 in. (26 percent) at room temperature. By comparison, the $\mathrm{BC} 1$ design had a residual interference of 0.005 in. (5 percent) at $2000{ }^{\circ} \mathrm{F}$ versus 0.029 in. (27 percent) at room temperature. After 20 load cycles, both seal designs had comparable amounts of residual interference at room temperature and $2000{ }^{\circ} \mathrm{F}$ respectively. These tests were performed as early feasibility studies to compare the resiliency and flexibility of the $\mathrm{BCl}$ design to the $\mathrm{ACl}$ design.
Because the $\mathrm{BC} 1$ design did not show an improvement in resiliency, additional work will need to be done to develop more resilient seal designs in conjunction with seal preloading devices for future high temperature seal applications.

Table 5 and Figure 12 also show that the loads were lower for both seal designs for each load cycle at $2000{ }^{\circ} \mathrm{F}$ than they were at room temperature. By the 20th load cycle, for example, the $\mathrm{BC} 1$ design reached a peak load of only $5.1 \mathrm{lbf} / \mathrm{in}$. at $2000^{\circ} \mathrm{F}$ as compared to $14.1 \mathrm{lbf} / \mathrm{in}$. for the 20th load cycle at room temperature, a drop in load of more than 60 percent. The seals were also less able to sustain loads during hold periods. As mentioned previously, each load cycle included a hold period in which the seal was held at the specified compression level for $1 \mathrm{~min}$. before it was unloaded. Figure 14 shows the amount of load on the $\mathrm{BC} 1$ design versus time for load cycles 1 through 10 and 20 of tests performed at room temperature and at $2000{ }^{\circ} \mathrm{F}$. For the first cycle of the room temperature test, the load fell from a peak of about $30 \mathrm{lbf} / \mathrm{in}$. at the start of the hold

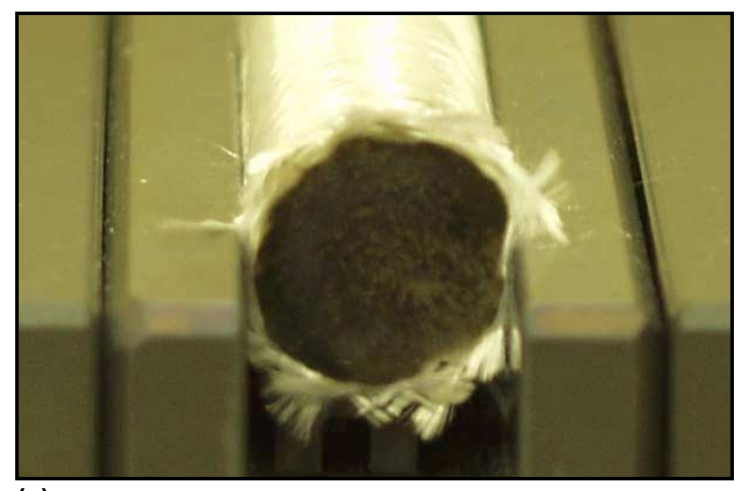

(a)

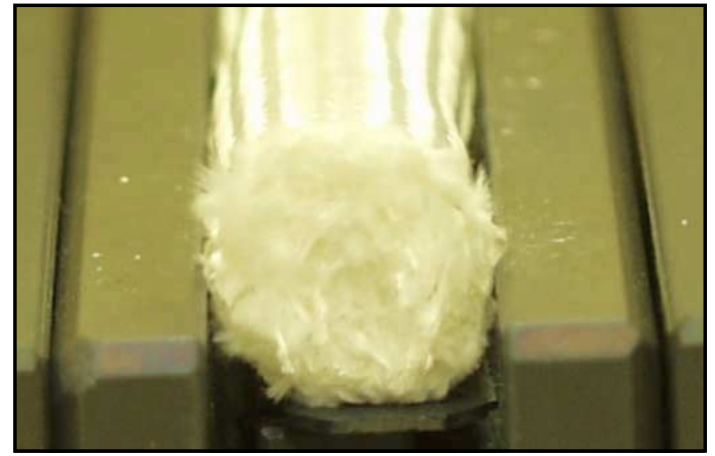

(c)

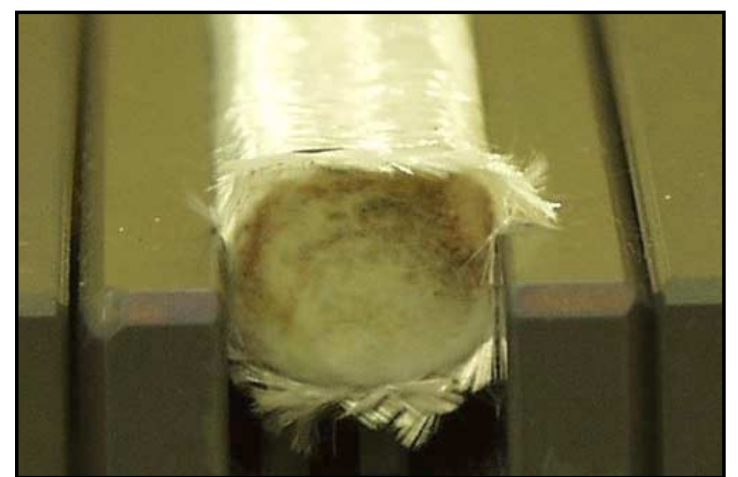

(b)

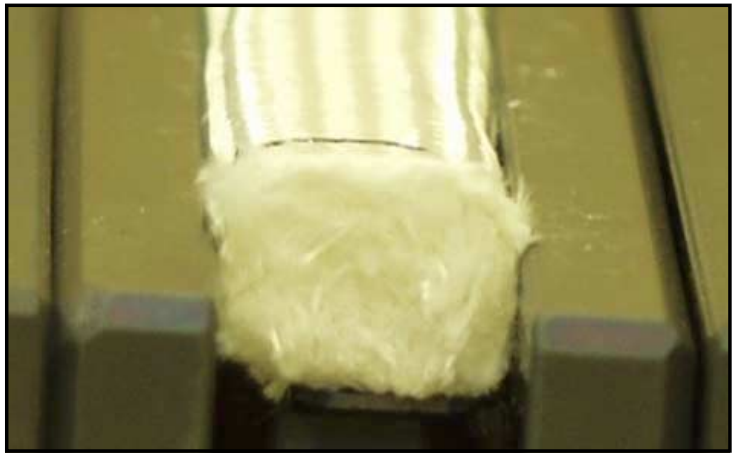

(d)

Figure 13.-Photographs of $A C 1$ seal design (a) before $2000^{\circ} \mathrm{F}$ compression testing and (b) after compression testing at $2000{ }^{\circ} \mathrm{F}$, and BC1 seal design (c) before $2000{ }^{\circ} \mathrm{F}$ compression testing and (d) after compression testing at $2000^{\circ} \mathrm{F}$. 


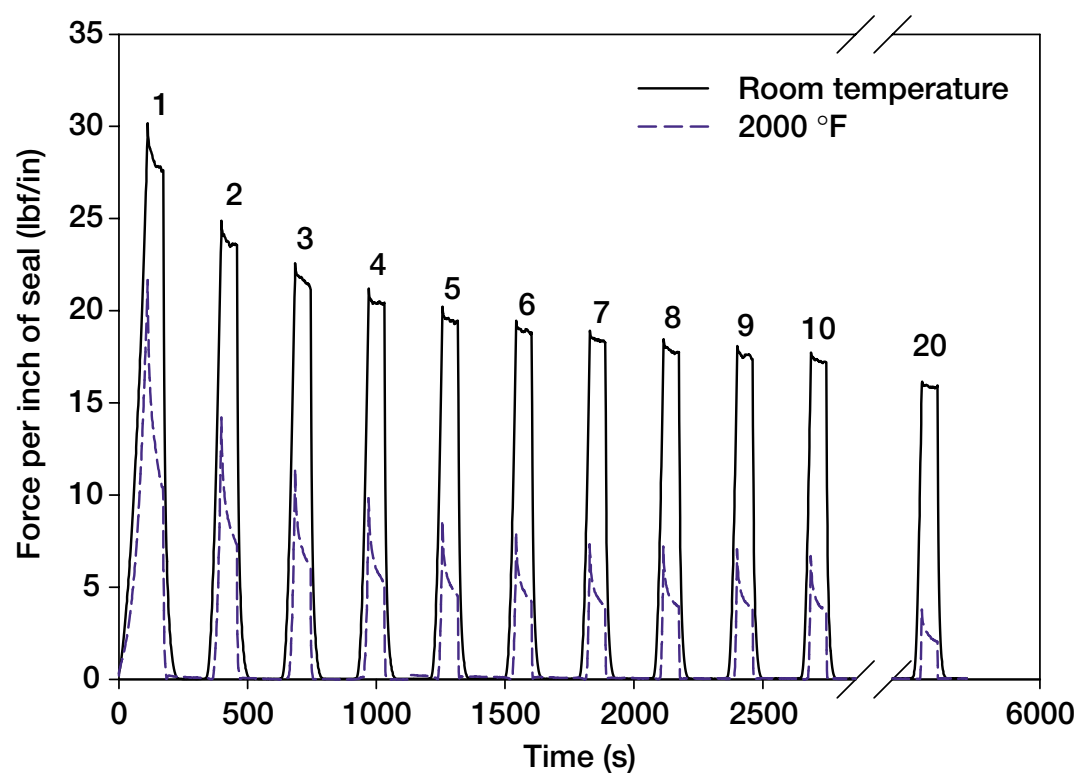

Figure 14.-Load vs. time for $\mathrm{BC} 1$ seal design at room temperature and $2000^{\circ} \mathrm{F}$ (load cycles other than 1-10 and 20 removed for clarity).

period to about $27 \mathrm{lbf} / \mathrm{in}$. at the end of the hold. This was a decrease of about 10 percent of the peak load. The load decreased by about $2 \mathrm{lbf} / \mathrm{in}$. or less during subsequent hold periods. In contrast, the load fell from a peak of about 22 to $10 \mathrm{lbf} / \mathrm{in}$. during the first load cycle at $2000{ }^{\circ} \mathrm{F}$, or more than 50 percent of the peak load. The load also dropped by about 50 percent in the ensuing hold periods. The AC1 seal design exhibited similar behavior. This drop in seal load during hold periods at $2000{ }^{\circ} \mathrm{F}$ could be a concern for hypersonic engine applications. Use of a seal preloading device behind the seals could provide better load stability for these seals at high temperatures.

\section{Compression Test Results: Canted Coil Springs}

In the room temperature compression tests on the canted coil springs, the springs were loaded to a linear compression of 0.220 in. A representative plot of the results is shown in Figure 15 for cycles 1, 10, and 20 of a test. During these tests, there was little hysteresis in the data as the loading and unloading portions of the curves were similar. In contrast to the performance of the seals, the springs became slightly stiffer with load cycling with cycles 10 and 20 reaching higher peak loads than the peak for cycle 1 . Because the springs stiffened with load cycling, they had no permanent set or relaxation after 20 load cycles.

The initial portion of the curve showed a gradual increase in force versus linear compression up to a deflection of about $0.060 \mathrm{in}$. where the load leveled off at about $6 \mathrm{lbf} / \mathrm{in}$. At this point, the curve flattened out and the force remained nearly constant until the spring deflection reached about $0.170 \mathrm{in}$. Over this $0.110 \mathrm{in}$. deflection range, the load slowly rose from 6 to $7 \mathrm{lbf} / \mathrm{in}$. The force on the spring rose sharply beyond deflections of $0.170 \mathrm{in}$. This unique force versus deflection curve is typical of a canted coil spring. ${ }^{5}$ The large deflection range in which the load remained nearly constant makes canted coil springs appealing as seal preloading devices because they could provide a large amount of stroke and resiliency to a seal without applying excessive loads to the seal or the opposing sealing surfaces.

Compression Test Results: Seals + Canted Coil Springs A series of room temperature compression tests was performed with each seal design on top of a canted coil spring to evaluate the resiliency and loads of these combined systems. The results of these tests are summarized in Table 5, and a plot of force versus linear compression for the $\mathrm{BC} 1$ design on top of a canted coil spring is shown in Figure 16. As indicated in Figure 16, the loading curves for the $\mathrm{BC} 1$ seal on top of a spring took on shapes that were a combination of the loading curves for the seal and spring individually. There was more hysteresis in the loading and unloading portions of each load cycle than there was for the canted coil spring by itself (Figure 15), but this amount of hysteresis was far less than that of the seal by itself (Figure 11). This behavior was also observed for the AC1 seal on top of a canted coil spring. 


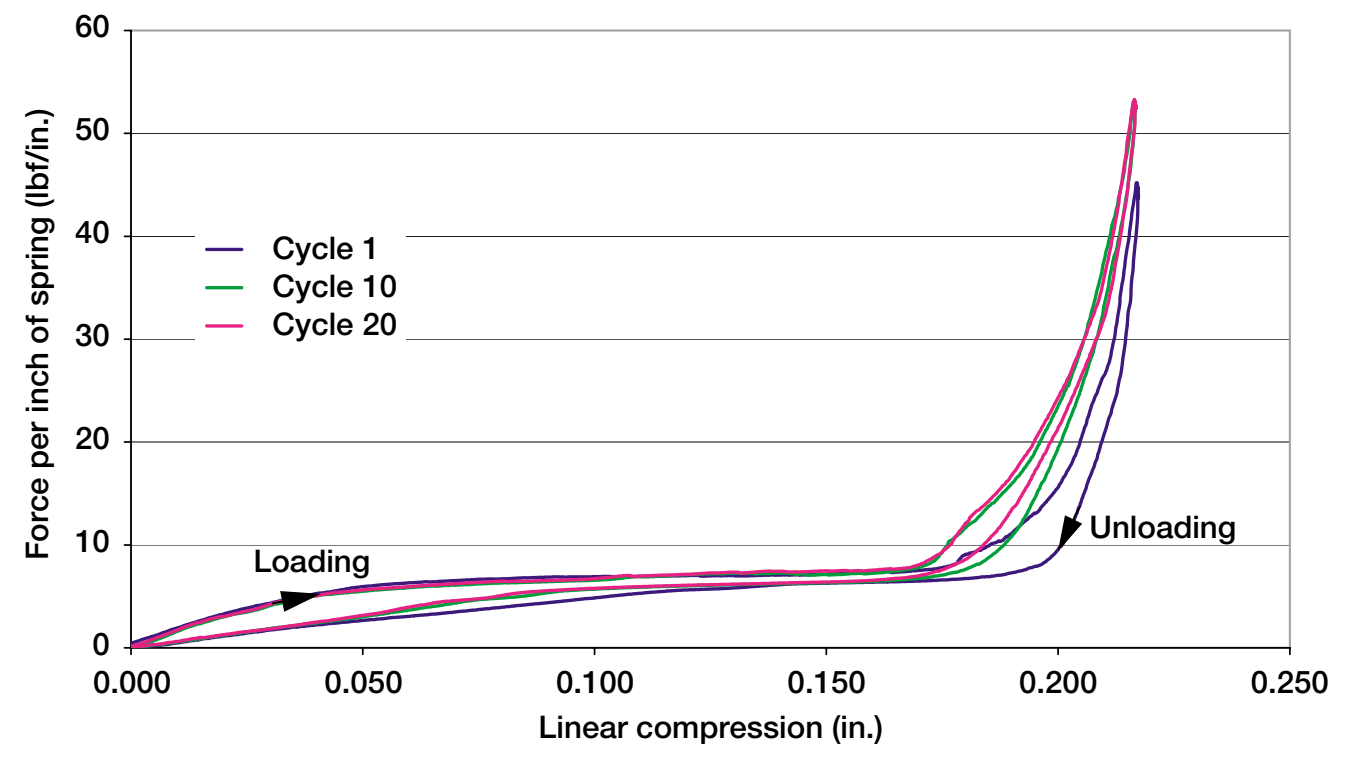

Figure 15.-Load vs. linear compression for canted coil spring at room temperature (load cycles other than 1, 10, and 20 removed for clarity).

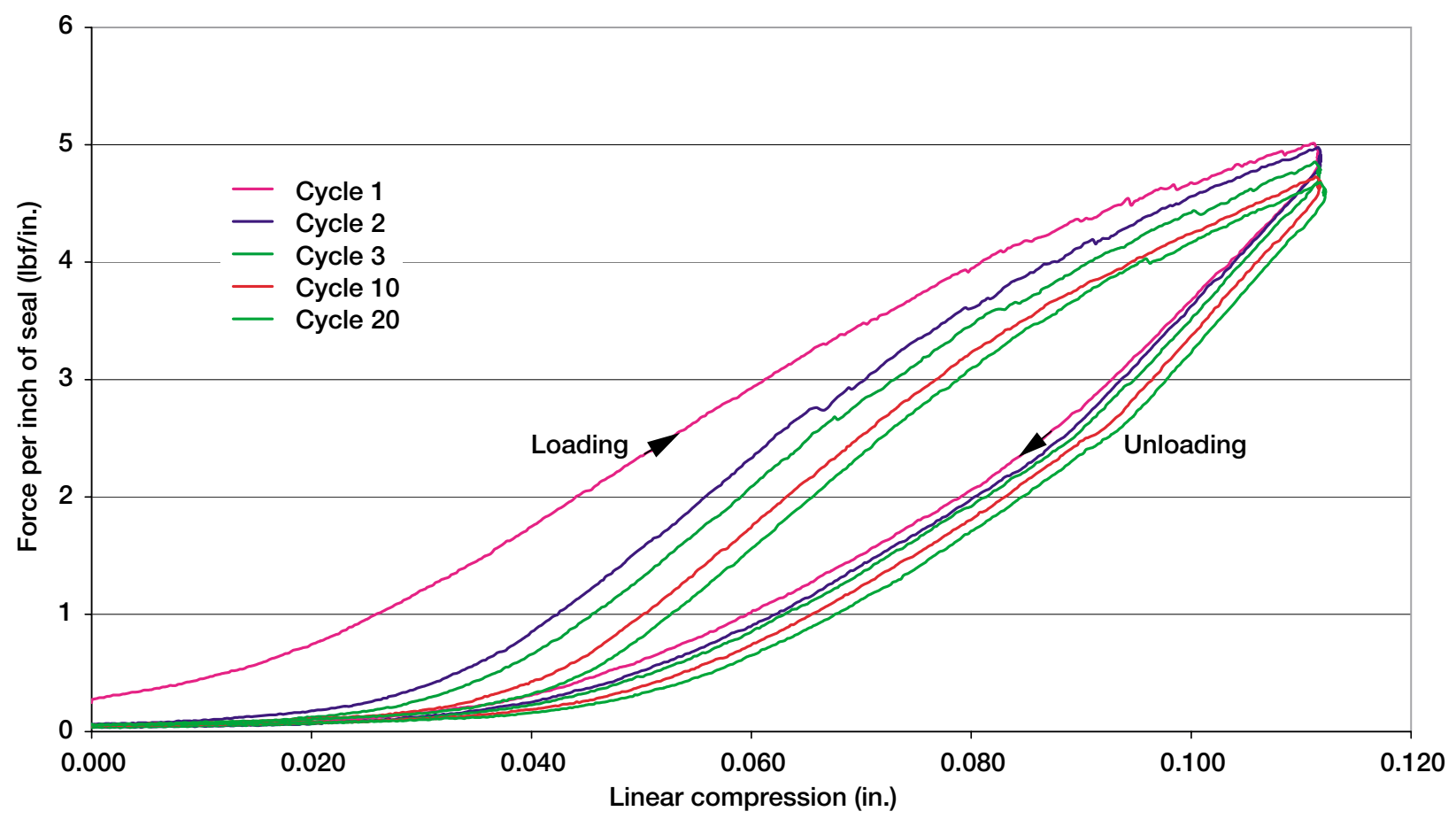

Figure 16.-Load vs. linear compression for BC1 seal design on top of canted coil spring at room temperature (load cycles other than $1,2,3,10$, and 20 removed for clarity). 
A similar situation occurred for residual interference. Whereas the canted coil spring did not take on any permanent set with load cycling (Figure 15), the combination of a seal on top of a spring showed some permanent set and decrease in residual interference with repeated loading (Table 5 and Figure 9). By the start of the 20th load cycle, the AC1 design on top of a spring had a residual interference of 0.071 in. or 60 percent of the total linear displacement. The $\mathrm{BC} 1$ seal on top of a spring performed even better with a residual interference of $0.079 \mathrm{in}$. (70 percent) by the start of the 20th load cycle. Because the spring by itself did not exhibit this decrease in residual interference, this must be due to permanent set in the seal with repeated loading.

Although there was some loss of resiliency for the seals on top of the springs, the combined system was much more resilient than the seals by themselves. Adding a spring behind the AC1 seal increased the amount of residual interference at the start of the 20th load cycle from 0.030 in. (26 percent) without the spring to 0.071 in. (60 percent) with the spring. Similarly, the residual interference for the $\mathrm{BC} 1$ seal at the start of the 20th load cycle increased from 0.029 in. (27 percent) to 0.079 in. (70 percent) when the spring was added. In each case, addition of a canted coil spring behind a seal improved the resiliency of the combined system by a factor of about 2.5.
While the shape of the loading curves for the seals on top of the canted coil springs was a combination of the loading curves for each device individually, the peak loads for the combined system were more similar to those for the spring by itself. As seen in Figure 15, the load generated by the spring at a linear compression in the range of 0.112 to $0.120 \mathrm{in}$. was about $6.5 \mathrm{lbf} / \mathrm{in}$. for cycles 1,10 , and 20 . For the combined seal/spring system, the peak loads were in a similar range. The peak loads for both seal designs on top of the springs dropped slightly from about $5 \mathrm{lbf} / \mathrm{in}$. for the first load cycle down to $4.6 \mathrm{lbf} / \mathrm{in}$. by the 20 th load cycle. The loads for each seal by itself at room temperature were much higher (Table 5). Thus, the peak loads reached by the combined seal/spring system were driven primarily by the stiffness of the spring.

In this study, tests were performed on canted coil springs made of stainless steel to evaluate their performance at room temperature. The authors recognize that the springs would have to be made out of a different material for applications at $2000+{ }^{\circ} \mathrm{F}$.

\section{Compression Test Results: Silicon Nitride Compression}

\section{Springs}

Figure 17 shows the results of the compression tests performed on the silicon nitride compression springs. To avoid breaking the springs, both designs were loaded to a linear compression that was about

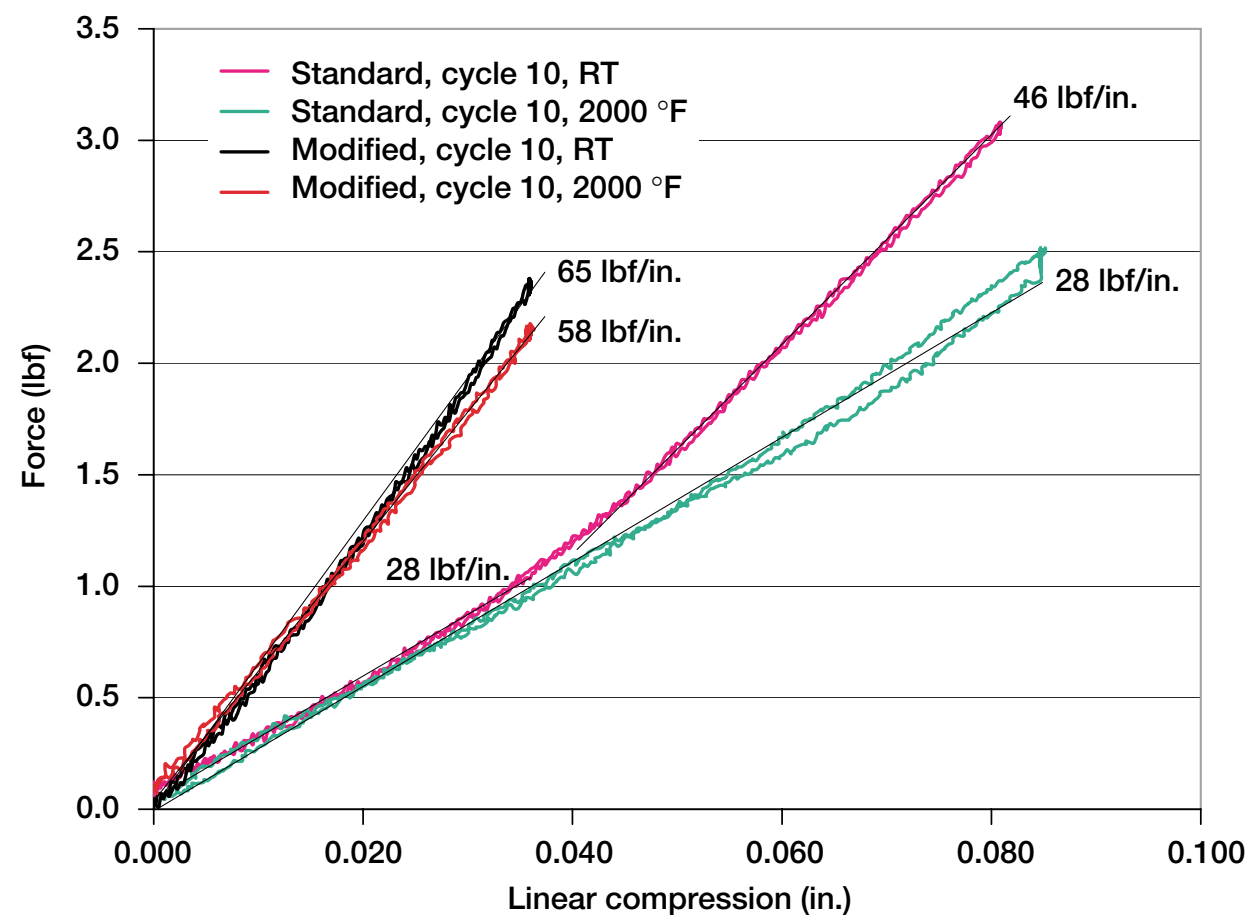

Figure 17.-Load vs. linear compression for silicon nitride compression springs at room temperature and $2000^{\circ} \mathrm{F}$ (load cycles other than 10 removed for clarity). 
85 percent of the maximum deflection specified by the manufacturer (Table 2). The standard springs were subjected to a linear compression of 0.083 in. and the modified spring design was compressed 0.036 in.

Spring constants for both spring designs are shown in Figure 17 both at room temperature and at $2000^{\circ} \mathrm{F}$. The modified spring design had a spring constant of $65 \mathrm{lbf} / \mathrm{in}$. at room temperature and $58 \mathrm{lbf} / \mathrm{in}$. at $2000^{\circ} \mathrm{F}$, possibly indicating that these springs became slightly less stiff at high temperatures. The standard spring design showed a different type of loading behavior, though. Its load versus linear compression curve at room temperature had two different regions. In the linear compression range up to about $0.040 \mathrm{in}$., the standard spring had a spring constant of about $28 \mathrm{lbf} / \mathrm{in}$. From 0.040 to 0.083 in., the spring became stiffer with a spring constant of $46 \mathrm{lbf} / \mathrm{in}$. This type of behavior did not occur during the test at $2000{ }^{\circ} \mathrm{F}$, though, as the spring constant remained at $28 \mathrm{lbf} / \mathrm{in}$ throughout the test.

For all of the tests performed on the silicon nitride springs, there was very little hysteresis in their load versus linear compression data. In each load cycle, the loading and unloading portions of the curve were almost identical. There was also no permanent set or relaxation in these springs either at room temperature or at $2000{ }^{\circ} \mathrm{F}$. For this reason, Figure 17 only shows the curves for cycle 10 of each test because they were almost identical to the curves for all other load cycles. These results show that the silicon nitride springs show promise for use as seal preloading devices because they remain resilient for multiple load cycles at temperatures up to $2000^{\circ} \mathrm{F}$.

The tests performed on the silicon nitride compression springs were "proof of concept" tests that showed that it is possible for a spring-like device to operate at high temperatures while still maintaining its load-bearing capabilities and resiliency. The specific spring designs that were evaluated did not meet all of the requirements described earlier for potential seal preloading devices in that they were taller than the requirements and did not provide the desired $0.1 \mathrm{in}$. of stroke. It is also likely that heavier duty springs would be required for applications in which higher loads are anticipated. Although these springs did not meet all of the requirements, their designs have not yet been optimized.

\section{Flow Test Results: AC1 Seal Design Versus BC1 Seal Design}

Seal flow rates at pressure differentials of 10 and 100 psid are summarized in Figure 18 at a nominal seal compression level of 20 percent with a 0.125 -in. seal gap. The flow rates shown in this figure are presented as the volumetric flow rate at room temperature divided by the length of seal exposed to flow in the test fixture. Although the test specimens were 4 in. long, only 3.46 in. of the seals were actually exposed to flow.

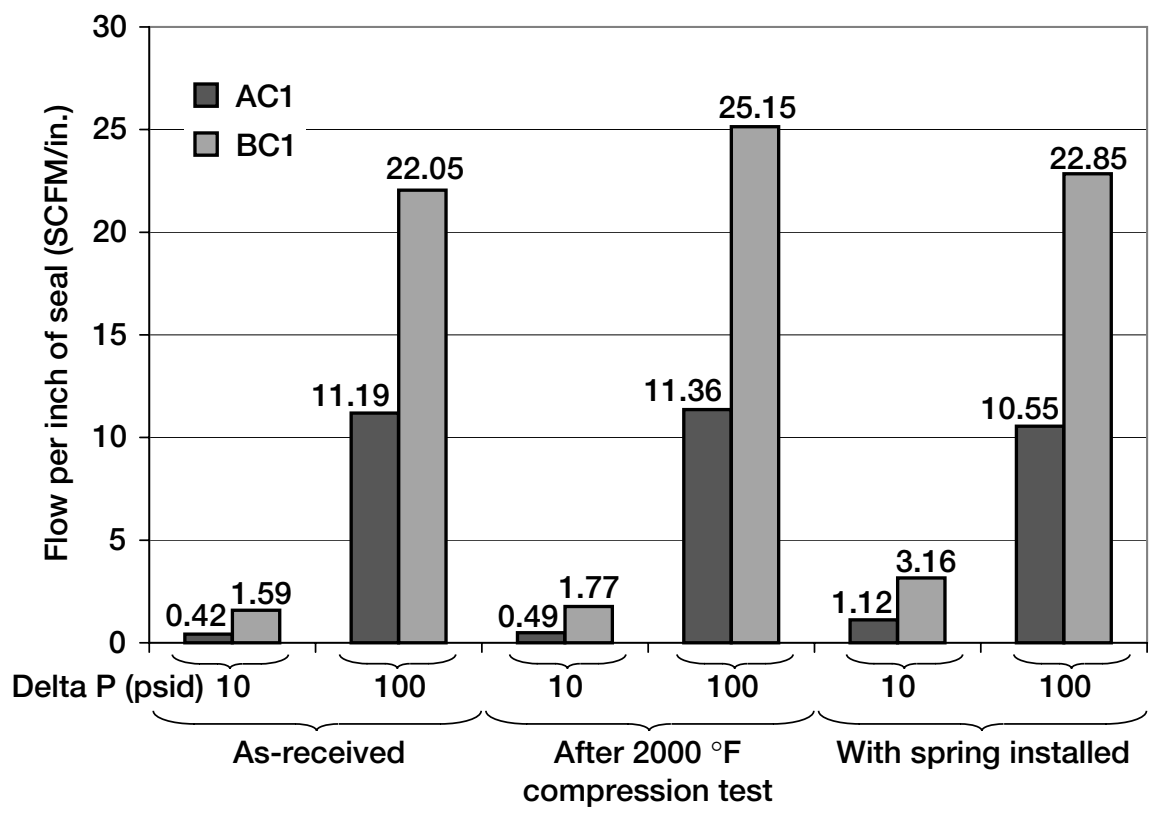

Figure 18.-The effect of pressure differential, $2000^{\circ} \mathrm{F}$ compression testing, and presence of canted coil spring on seal flow rates for a gap size of 0.125 in. 
The results in Figure 18 show that the flow rates for the $\mathrm{AC} 1$ seal design were lower than those for the $\mathrm{BC} 1$ design for all cases that were tested. For the as-received seals, the amount of flow through the $\mathrm{BC} 1$ design was 3.8 times higher than for the $\mathrm{AC} 1$ design at a pressure of 10 psid across the seals and almost 2 times higher at 100 psid. Similar ratios were observed for the seals that had been compression tested at $2000{ }^{\circ} \mathrm{F}$ and for those that were tested with canted coil springs behind them. These results indicate that the dense core of uniaxial fibers in the $\mathrm{AC} 1$ design was more effective at blocking flow than the braided core of the $\mathrm{BC} 1$ design. This is to be expected because the uniaxial fibers in the AC1 seal were packed together more tightly than the braided structure in the BC1 seal in which pores were created where the core sub-elements crossed over each other. It may be possible to produce other seal designs in the future that block flow better than the $\mathrm{BC} 1$ design does while still providing the flexibility that the $\mathrm{BC} 1$ seal exhibited.

Flow Test Results: As-Received Seals Versus Seals Compression Tested at $2000^{\circ} \mathrm{F}$

Flow rates through the seals that had been compression tested at $2000^{\circ} \mathrm{F}$ were about the same as those for the as-received seals (Figure 18). There was only a small increase in flow for the compression-tested seals indicating that any additional loss of resiliency due to compression testing at $2000{ }^{\circ} \mathrm{F}$ did not have much effect on the seals' ability to restrict flow.

\section{Flow Test Results: Effect of Canted Coil Springs Behind Seals}

Figure 18 shows that flow rates were higher at 10 psid for the seals with canted coil springs installed behind them than they were for the as-received seals with no springs installed. At this pressure, flow rates for the AC1 design with a spring behind it were about 2.7 times higher than without the spring, and those for the $\mathrm{BC} 1$ design were about twice as high with a spring. In contrast, the flow rates at 100 psid for both seal designs with springs behind them were comparable to those with no spring installed. Two factors were believed to have played a role in this difference. Although the AC1 design had a nominal diameter of 0.600 in. and the $\mathrm{BC} 1$ design was 0.565 in. in diameter, they were tested in a standard groove that was 0.620 in. wide. With no spring installed behind the seals, they were able to deform and contact the side walls of the groove when they were compressed. This configuration allowed the seals to fill the groove and restrict flow better. For the tests in which a spring was installed behind the seals in a deeper groove, much of the deformation likely occurred in the spring causing less contact between the undersized seals and the groove side walls. At lower pressures (e.g., 10 psid), more air flow would be able to sneak into the groove behind the seals when a spring was present than without a spring. At higher pressures (e.g., 100 psid), though, the larger pressure differential across the seals would act to seat them into the groove better by pushing them into contact with the groove side wall on the downstream side of the seal. This phenomenon would explain why the flow rates with a spring installed were higher at 10 psid than without a spring but comparable at 100 psid.

\section{SUMMARY AND CONCLUSIONS}

NASA GRC developed a variety of high temperature structural seals during the NASP program, but those seals fell short of program goals and due to program termination could not be adequately matured. Current requirements for advanced hypersonic engines are even more demanding, and the current SOA seals do not meet these requirements. To overcome the shortfalls of SOA seals, GRC is developing advanced seals under NASA's NGLT program. Shortfalls that were investigated in the current study included a loss of seal resiliency with load cycling at high temperatures, lack of seal flexibility, and seal flow blocking ability. In an effort to address these shortfalls, two seal designs and two types of seal preloading devices were evaluated in a series of flow tests at room temperature and compression tests at room temperature and $2000{ }^{\circ} \mathrm{F}$. Based on the results of these tests, the following conclusions are made:

1. Both the NASP-generation $\mathrm{AC} 1$ seal design with its core of uniaxial fibers and the $\mathrm{BC} 1$ seal design with its braided core structure lost resiliency with repeated loading at high temperatures. After 20 load cycles at room temperature, these seals had a residual interference of about 26 percent of the total linear compression applied to them. At $2000^{\circ} \mathrm{F}$, the residual interference dropped to 5 to 6 percent after 20 load cycles. Additional work will need to be done to develop seals that have more resiliency after repeated load cycling.

2. Although the $\mathrm{BC} 1$ seal design had about the same amount of resiliency as the AC1 design, its braided core allowed it to be as much as 30 times more flexible than the AC1 design. This added flexibility makes the $\mathrm{BC} 1$ design able to seal around corners in locations of a hypersonic engine where the $\mathrm{ACl}$ design would not be able to.

3. Canted coil springs are promising seal preloading devices. Adding a canted coil spring behind the seals improved seal residual interference at room 
temperature from about 26 percent without the spring to as much as 70 percent for the $\mathrm{BC} 1$ design with the spring. These feasibility tests were performed on springs made of stainless steel. High temperature materials will need to be used for applications at $2000+{ }^{\circ} \mathrm{F}$.

4. Silicon nitride compression springs also show promise as high temperature seal preloading devices. After repeated loading at $2000{ }^{\circ} \mathrm{F}$ the springs showed little hysteresis and excellent resiliency.

5. Flow rates for the $\mathrm{BC} 1$ seal design were 2 to 3.8 times higher than those for the $\mathrm{AC} 1$ seal design. The dense core of uniaxial fibers in the AC1 design served as a better flow blocker than the braided core of the $\mathrm{BC} 1$ design.

The results of these tests indicated that more work needs to be done to develop seals with better resiliency. However, two spring designs were identified as promising seal preloading devices that could help overcome the lack of resiliency in these seals.

\section{REFERENCES}

1. Steinetz, B.M., DellaCorte, C., Machinchick, M., Mutharasan, R., Du, G., Ko, F., Sirocky, P.J., and Miller, J.H., "High Temperature Dynamic Engine Seal Technology Development," NASA TM105641, April 1992.

2. Tong, M.T. and Steinetz, B.M., "Thermal and Structural Assessments of a Ceramic Wafer Seal in Hypersonic Engines," NASA TM-103651, June 1991.

3. Steinetz, B.M. and Adams, M.L., "Effects of Compression, Staging, and Braid Angle on Braided Rope Seal Performance," Journal of Propulsion and Power, Vol. 14, No. 6, 1998, pp. 934-940.

4. Silicon Nitride Ceramic Spring product literature, NHK Spring Co., Ltd., KK9502-6-1P, pp. 3-4.

5. Canted Coil Spring product literature, Bal Seal Engineering Company, Inc., Catalog No. 3.1E, p. 2. 
Public reporting burden for this collection of information is estimated to average 1 hour per response, including the time for reviewing instructions, searching existing data sources, gathering and maintaining the data needed, and completing and reviewing the collection of information. Send comments regarding this burden estimate or any other aspect of this collection of information, including suggestions for reducing this burden, to Washington Headquarters Services, Directorate for Information Operations and Reports, 1215 Jefferson Davis Highway, Suite 1204, Arlington, VA 22202-4302, and to the Office of Management and Budget, Paperwork Reduction Project (0704-0188), Washington, DC 20503.

\begin{tabular}{|l|l|l|}
\hline 1. AGENCY USE ONLY (Leave blank) & $\begin{array}{c}\text { 2. REPORT DATE } \\
\text { July } 2003\end{array}$ & $\begin{array}{r}\text { 3. REPORT TYPE AND DATES COVERED } \\
\text { Technical Memorandum }\end{array}$ \\
\hline
\end{tabular}

4. TITLE AND SUBTITLE

5. FUNDING NUMBERS

Toward an Improved Hypersonic Engine Seal

6. AUTHOR(S)

Patrick H. Dunlap, Jr., Bruce M. Steinetz, Jeffrey J. DeMange, and Shawn C. Taylor

\section{PERFORMING ORGANIZATION NAME(S) AND ADDRESS(ES)}

National Aeronautics and Space Administration

John H. Glenn Research Center at Lewis Field

Cleveland, Ohio 44135-3191

WBS-22-713-82-31

\section{SPONSORING/MONITORING AGENCY NAME(S) AND ADDRESS(ES)}

National Aeronautics and Space Administration

Washington, DC 20546-0001

8. PERFORMING ORGANIZATION REPORT NUMBER

E-14093

11. SUPPLEMENTARY NOTES

Prepared for the 39th Joint Propulsion Conference and Exhibit cosponsored by AIAA, ASME, SAE, and ASEE, Huntsville, Alabama, July 20-23, 2003. Patrick H. Dunlap, Jr. and Bruce M. Steinetz, NASA Glenn Research Center; Jeffrey J. DeMange, University of Toledo, Toledo, Ohio 43606; Shawn C. Taylor, Case Western Reserve University, Cleveland, Ohio 44106 and Summer Internship at Ohio Aerospace Institute, Brook Park, Ohio. Responsible person, Patrick H. Dunlap, Jr., organization code 5950, 216-433-3017.

12a. DISTRIBUTION/AVAILABILITY STATEMENT 12b. DISTRIBUTION CODE

Unclassified - Unlimited

Subject Category: 37

Distribution: Nonstandard

Available electronically at http://gltrs.grc.nasa.gov

This publication is available from the NASA Center for AeroSpace Information, 301-621-0390.

13. ABSTRACT (Maximum 200 words)

High temperature, dynamic seals are required in advanced engines to seal the perimeters of movable engine ramps for efficient, safe operation in high heat flux environments at temperatures from 2000 to $2500{ }^{\circ} \mathrm{F}$. Current seal designs do not meet the demanding requirements for future engines, so NASA's Glenn Research Center (GRC) is developing advanced seals to overcome these shortfalls. Two seal designs and two types of seal preloading devices were evaluated in a series of compression tests at room temperature and $2000^{\circ} \mathrm{F}$ and flow tests at room temperature. Both seals lost resiliency with repeated load cycling at room temperature and $2000^{\circ} \mathrm{F}$, but seals with braided cores were significantly more flexible than those with cores composed of uniaxial ceramic fibers. Flow rates for the seals with cores of uniaxial fibers were lower than those for the seals with braided cores. Canted coil springs and silicon nitride compression springs showed promise conceptually as potential seal preloading devices to help maintain seal resiliency.

\section{SUBJECT TERMS}

Seals; Flow; Design; Test; High temperature

17. SECURITY CLASSIFICATION OF REPORT

Unclassified

\section{SECURITY CLASSIFICATION OF THIS PAGE \\ Unclassified}

19. SECURITY CLASSIFICATION OF ABSTRACT

Unclassified
15. NUMBER OF PAGES

25

16. PRICE CODE

20. LIMITATION OF ABSTRACT

Standard Form 298 (Rev. 2-89)

Prescribed by ANSI Std. Z39-18 298-102 